\title{
Faunal Activities and Soil Processes: Adaptive Strategies That Determine Ecosystem Function
}

\author{
P. LAVELLE
}

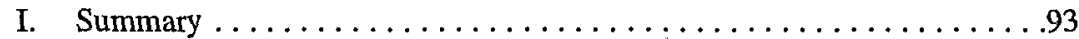

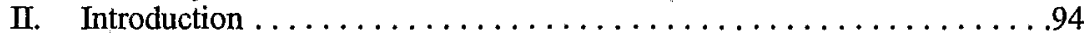

III. The role of invertebrates in the soil system $\ldots \ldots \ldots \ldots \ldots \ldots \ldots 96$

IV. Adaptive strategies of soil organisms: the sleeping beauty and the

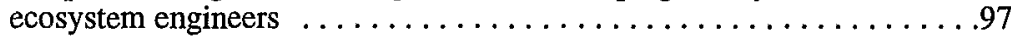

V. Microfauna: microbial regulation in micro-foodwebs ........... 101

A. The composition of micro-foodwebs $\ldots \ldots \ldots \ldots \ldots \ldots \ldots \ldots 1$

B. Distribution and dispersal of microsites . . . . . . . . . . . 103

C. Evidence for the functional importance of

micro-foodwebs: effects on SOM dynamics . . . . . . . . . . . . . 104

VI. Saprophagous arthropoda: the litter transformers .............105

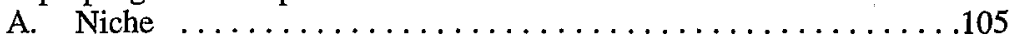

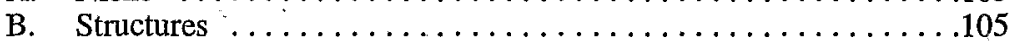

C. Effects on physical parameters of soil $\ldots \ldots \ldots \ldots \ldots \ldots \ldots \ldots$...........

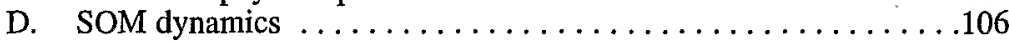

E. Effects on plant growth in microcosms ................108

VII. Termites and earthworms: the ecosystem engineers .............108

A. Roles ..................................

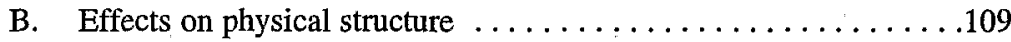

C. Effects on SOM dynamics ..........................

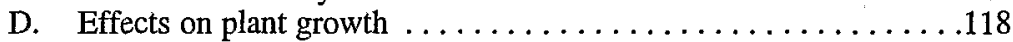

VIII. Conclusions ....................................120

References .......................................122

\section{SUMMARY}

Soils host an extremely diverse community of invertebrates that differ in their adaptive strategies and hence in the functions they fulfil in soils. Soil invertebrates have relatively limited abilities to digest soil resources and rely to a large extent on micro-organisms to derive the assimilates they need from soil 
organic resources. Conversely, activation of microflora by larger organisms appears to be essential to the maintenance and enhancement of activity of microbial communities. A paradigm is proposed (the 'Sleeping Beauty Paradox') that explains the overall mechanism of these interactions. Three major groups of invertebrates may be defined based on the nature of the relationship that they develop with soil microflora. This classification sets special emphasis on the creation of structures by invertebrates, and on the nature of these structures. The microfauna comprises invertebrates of less than $0.2 \mathrm{~mm}$ on average that live in water filled soil pore space. They do not create structures and they make use of micro-organisms mainly through predation in micro-foodweb systems. Mesofauna (= invertebrates $0.2-2 \mathrm{~mm}$ in size) and large arthropods comprise the group of litter transformers that create purely organic structures (their faecal pellets) inside which a mutualist relationship ('external rumen digestion') develops. Earthworms, termites and, to a lesser extent, ants, are 'ecosystem engineers' that create diverse organo-mineral structures and interact with micro-organisms through an internal rumen type of digestion. Dynamics of organic matter are largely influenced by the nature and persistence in time of structures created by invertebrates. Holorganic structures made by litter transformers allow a two-phase dynamics of organic matter (i.e., acceleration of mineralisation in a short time scale followed by a significant reduction due to compaction of the structure). Organomineral structures have a comparable effect on soil organic matter dynamics, but they may last for much longer periods. Because of their diversity and occasional abundance, these structures may significantly influence organic matter dynamics and soil physical properties, especially porosity and aggregation that determine water storage and circulation, and hence, potential erosion.

It is suggested that the three systems defined operate at nested scales of time and space and have decreasing overall effects on the determination of soil function in the order micro-foodwebs < litter transformers < ecosystem engineers. Nonetheless, ecosystem engineers are less able to withstand high levels of natural or anthropogenic environment constraints and lower order groups may become predominant with significant differences in the function of the ecosystem. Modifications of soil fauna communities may lead to losses of diversity and result in losses of functions when specific structural patterns or regulation mechanisms are lost.

\section{INTRODUCTION}

Soils host an extremely high diversity of organisms. In one hectare of temperate forest, several hundred species of soil invertebrates may coexist (Schaefer and Schauerman, 1990; André et al., 1994). It has been - and it still is - an enormous task for zoologists to identify and classify all these species. However, the perception of the functional importance of soil invertebrates is 
as old as the interest for their classification. Aristotle called earthworms 'the intestine of the earth' and Darwin was the first of a long lineage of zoologists who have been fascinated by the unwearying and multifarious activity of earthworms. His book The Formation of Vegetable Mould Through the Action of Worms with Observations on Their Habits (1881) and the work of Müller on humus forms (1887) are still famous products of an active scientific community which created soil ecology (Bal, 1982). At the same time, Dokuchaev (1889) formulated the basic concepts of pedology, but soil biology and pedology have largely ignored each other for several decades while they devoted considerable efforts to classifications and the separate elucidation of basic processes.

In the 1970s, the International Biological Programme produced a large amount of quantitative data on the abundance of soil invertebrates and their participation to fluxes of energy in the ecosystem (see e.g., Petersen and Luxton, 1982). It was concluded that their direct participation to the release of $\mathrm{CO}_{2}$ from soils was limited to a few percent of the total, micro-organisms being by far the major producers of $\mathrm{CO}_{2}$. During the following decade, considerable efforts were devoted to the description and quantification of the direct and indirect effects of soil invertebrates on major processes of the soil function, i.e. regulation of microbial activities, the dynamics of soil organic matter and nutrient cycling, and the formation and maintenance of the physical structure (Lavelle, 1978; Coleman, 1985; Anderson et al., 1983; Eschenbrenner, 1986; Barois, 1987; Martin, 1991; Andren et al., 1990; Blanchart, 1992). Experiments in small laboratory designs called microcosms, and field observations and experimentations, mainly developed over short time periods, gave a large amount of results, sometimes quite contradictory (Anderson, 1987). The effects of soil invertebrate activities on plant growth have been considered in a number of studies, as a means ultimately to test their effects on fertility (Stockdill, 1959, 1982; Setälä and Huhta, 1991; Spain et al., 1992; Okello-Oloya and Spain, 1986; Pashanasi et al., 1992).

These experiments have demonstrated that (1) in small laboratory designs, soil invertebrates often have effects which are largely disproportionate to their abundance and biomass, especially on short-term processes such as the release of mineral- $\mathrm{N}$ and $\mathrm{P}$ from decomposing litter, or aggregation of soil; (2) in field conditions, these short term effects may not be significant over a greater scale of time and space since climate, soil characteristics or the chemical composition of organic matter may have a larger impact in the determination of soil processes than invertebrate activities. Under specific conditions, however, invertebrate pests, e.g., phytoparasitic nematodes or coleopteran larvae may have dramatic effects on crop production.

The rise of problems linked to soil management has recently stimulated the development of multifactorial experimental approaches which attempt to integrate biological, chemical and physical soil components and processes into 
comprehensive models of soil function. They have been applied to maintain the sustainability of soil fertility, monitor the storage and release of carbon and pollutants in a globally changing environment, and to quantify and understand the function of biodiversity (Coleman et al., 1984a, 1989; Swift, 1986; Anderson and Flanagan, 1989; Lavelle et al., 1993; Moore et al., 1993).

Two major kinds of approaches may be distinguished: the foodweb approach that tries to describe and quantify fluxes of carbon and nutrients through trophic networks associating mainly Protozoa, nematodes and microarthropods to micro-organisms, and evaluate the impact of such interactions on soil-plant systems (Ingham et al., 1986; Andren et al.; 1990; Moore and De Ruiter, 1991). The other approach considers 'Biological systems of regulation', i.e. large entities such as earthworms or termites or roots and the part of the soil that they influence, and tries to elucidate mechanisms of the soil function at the scale of these specific units (Lee and Wood, 1971; Coleman et al., 1984b; Lavelle, 1984; Clarholm, 1985; Lee, 1985; Wood, 1988; Abbadie and Lepage, 1989; Lavelle et al., 1992c).

This paper aims first at linking these diverse approaches into a general conceptual model of the relationships between soil invertebrates and the other animate and inanimate components of the soil system. A functional classification of soil organisms based on their adaptive strategies is then attempted. Three large functional groups (guilds) of soil invertebrates are defined and their effects on soil organic matter dynamics, nutrient cycling and the soil physical structure are detailed.

\section{THE ROLE OF INVERTEBRATES IN THE SOIL SYSTEM}

Soils receive energy that flows through the ecosystem in the form of (1) biological energy as dead organic matter, (2) physical energy, i.e. the convective and diffusive energies linked to water infiltration and drainage and temperature changes, and (3) chemical energy released by oxidations and hydrolyses.

Physical and chemical energies are largely dissipated through the processes of soil formation. These involve alteration and fragmentation of the bedrock at scales of time of a minimum of 10000 years, and a minimum spatial scale of (e.g.) a water catchment. Biological energy received as decomposing residues is dissipated along the decomposer foodweb at much shorter scales of time and space. The energy flow based on the decomposition of organic resources creates structures and releases partially reduced chemical compounds which further participate in the above-mentioned processes of alteration by means of oxidative reactions (Berthelin et al., 1979). Soil faunal activities may become significant determinants of pedogenesis, e.g. when they facilitate the stabilisation of acid organic compounds by mixing them to clay mineral elements, or when they accumulate organomineral pellets which 
are the component elements of aggregated structures. In some cases the participation of earthworm casts to the formation of soils is so evident that they have been called vermisols (Nye, 1955; Wielemaker, 1984, Eschenbrenner, 1986; Pop and Postolache, 1987).

Decomposition of organic residues is almost a purely biological process: 80-99.9\% of $\mathrm{CO}_{2}$ released by soils are issued from oxidative digestion processes (Seastedt et al., 1987; Moorehead and Reynolds, 1989; Scharpenseel et al., 1989). The rates at which this energy flows, and the forms that it takes, are determined by environmental factors and specific properties of soil organisms. Interactions with other organisms and the creation of specific microsites where these interactions occur, are characteristic features of the impact of organisms on soil processes.

Soil invertebrate activities are part of the multiple factors that determine microbial activities. Physical and chemical determinants, and the effects of soil invertebrates, operate at different scales of time and space; this network of interactions among all these determinants of microbial activities may be best represented by a hierarchical model in which climatic factors that operate at the largest scale of time and space are likely to constrain edaphic determinants (especially the abundance and mineralogy of clays and nutrient stocks), the quality of organic inputs, and finally activities of soil invertebrates and roots (Lavelle et al., 1993; Figure 1).

Soil micro-organisms, roots and invertebrates have complementary adaptive strategies whereby they influence three major processes in soils, i.e. decomposition and the dynamics of soil organic matter, the formation and maintenance of the soil structure, and nutrient and water supply to plants.

\section{ADAPTIVE STRATEGIES OF SOIL ORGANISMS: THE SLEEPING BEAUTY AND THE ECOSYSTEM ENGINEERS}

Soil organisms have evolved in an environment that imposes three major requirements, (1) to move in a compact environment with a loosely connected porosity, (2) to feed on low-quality resources and (3) to adapt to the occasional drying or flooding of the porous space (Lavelle, 1988). A continuum of adaptive strategies based on size is observed in soils, from micro-organisms to macroinvertebrates (Swift et al., 1979). The apparent contradiction between the short potential generation time of micro-organisms $(\mathrm{ca} 20 \mathrm{~h}$, Clarholm and Rosswall, 1980) and their slow turnover time (1-1.5 years, e.g. Jenkinson and Rayner, 1977; Chaussod et al. 1986) has been defined as the 'sleeping beauty paradox' based on evidence that soil invertebrates and root activities were necessary to stimulate this dormant microflora (Lavelle $e t$ al., 1994). Microbial communities are both numerous and diverse, but they are largely dormant. Their inability to move in the compact soil environment limits their activity to the immediate microsite in which they reside. They are to 


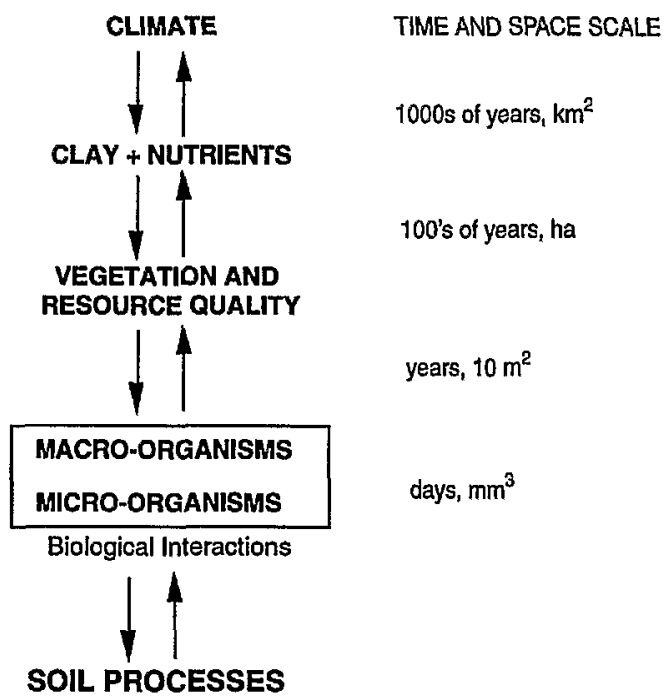

Fig. 1. An hierarchical model of the factors determining soil processes in terrestrial ecosystems (modified from Lavelle et al., 1993).

a great extent dependent on larger organisms, roots and soil fauna, for access to new substrates. Among the organisms thus acting as 'Prince Charmings', special attention is paid to the 'ecosystem engineers', i.e. those that are able to modify the soil environment through their mechanical activities (Stork and Eggleton, 1992).

Soil invertebrates have a continuum of strategies from the smallest microfauna that colonize the water-filled pore space in the same way as do microorganisms, to macrofauna that alter the soil environment to their own needs. The size of invertebrates and the aquatic or aerial nature of their respiration, reflect their way of adapting to spatial constraints. Three groups have been distinguished (Bachelier, 1978; Swift et al., 1979), i.e.

(1) Microfauna, which comprise aquatic invertebrates living in the waterfilled soil porosity. They are small, less than $0.2 \mathrm{~mm}$, on average, and mainly include Protozoa and Nematodes, plus other groups of lesser importance like tardigrades, rotifers

(2) Mesofauna, which comprise microarthropods (mainly collembolans and acarids) and the small Oligochaeta, Enchytraeidae, which have an average size of $0.2-2 \mathrm{~mm}$ and live in the air-filled pore space of the soil and litter

(3) Macrofauna, which include invertebrates larger than $2 \mathrm{~mm}$, on average. Termites, earthworms and large arthropods are the main components of this group. They have the ability to dig the soil and create specific 
structures for their movements and living activities (e.g. burrows, galleries, nests and chambers) plus casts and faecal pellets resulting from their feeding activities. These organisms have also been called 'ecosystem engineers' for their ability to profoundly affect the soil structure and hence major soil processes via the structures that they build (Stork and Eggleton, 1992).

Soil invertebrates have limited ability to digest the complex organic substrates of the soil and litter, but many have developed interactions with microflora that permit them to exploit soil resources. With increasing size, the relationship between microflora and fauna gradually shifts from predation to mutualisms of increasing efficiency. The concept of a foodweb becomes more and more difficult to apply as the trophic structure becomes increasingly, 'fluid and interactive with individual species operating on several levels which might be distinguished as trophically different' (Swift et al., 1979). Excrement of invertebrates is of the utmost importance in the evolution of organic matter (Martin and Marinissen, 1993), in the formation and maintenance of soil structure and, over long periods of time, to specific pedological processes called 'zoological ripening of soils' (Bal, 1982).

Three major guilds of soil invertebrates may be distinguished on the basis of the relationship that they have with soil micro-organisms and the kind of excrement that they produce (Figure 2).

Micro-foodwebs mainly comprise microfauna that are predators of bacteria and fungi, and their predators. Microfauna do not appear to produce recognizable solid excrements and hence, the effect of these invertebrates on soil organic matter dynamics is not prolonged in structures that are stable for some time after deposition. They have, however, a significant impact on population dynamics of micro-organisms and the release of nutrients immobilised in microbial biomass (Trofymow and Coleman, 1982; Clarholm, 1985). This process is especially developed in the rhizosphere. Predatory Acarina or Collembola, and even larger invertebrates (earthworms) may extend this foodweb over several trophic levels.

Litter transformers mainly comprise mesofauna and large arthropods which normally ingest purely organic material and develop an external ('exhabitational' sensu Lewis, 1985) mutualism with microflora based on the 'external rumen' (Swift et al., 1979). Litter arthropods may digest part of the microbial biomass or develop mutualistic interactions in their faecal pellets: in these structures, organic resources which have been fragmented and moistened during the gut transit, are actively digested by microflora. After some days of incubation, arthropods often reingest their pellets and absorb the assimilable organic compounds that have been released by microbial activity, and occasionally, part of the microbial biomass (Hassal and Rushton, 1982). This specific type of exhabitational mutualism is called the external rumen type of digestion (Swift et al., 1979). Inside this general adaptive strategy, a 


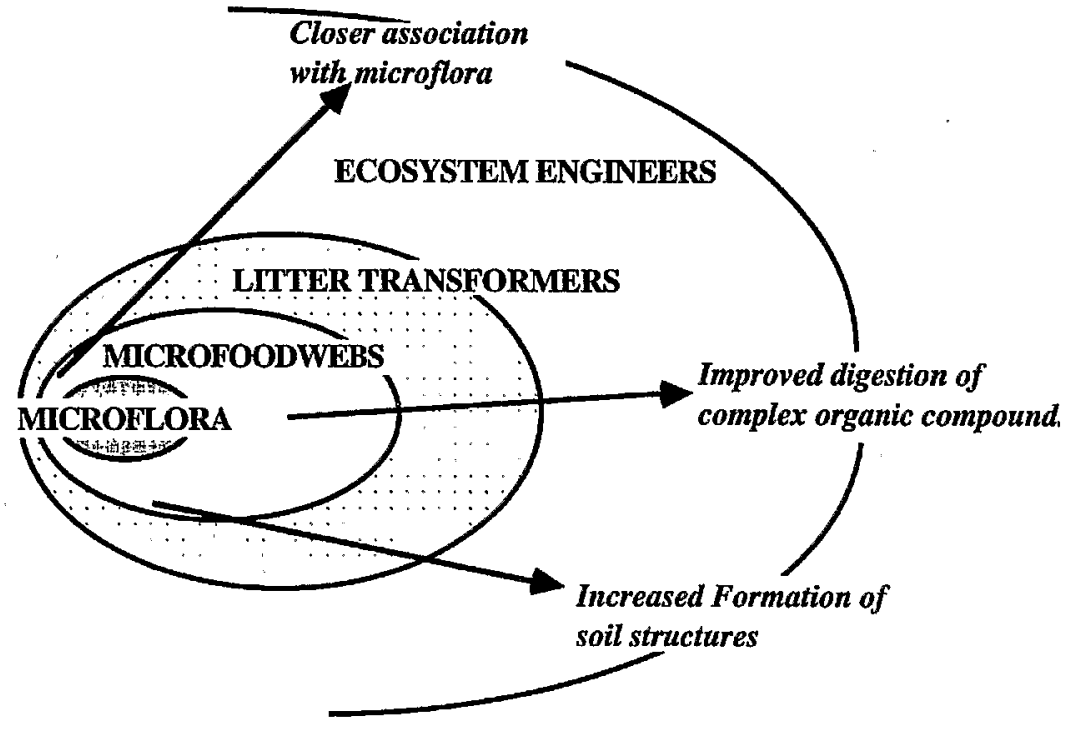

Fig. 2. Regulation of microbial activities by three guilds of soil invertebrates operating at increasing scales of time and space.

large diversity of behaviours may be identified (Vannier, 1985). Some insects such as Diptera (Sciaridae) which have comparatively efficient enzymatic machinery produce liquid faeces that they never reingest (Deleporte and Rouland, 1991). Their digestion system is not able to digest tannin-protein compounds and highly polymerized polysaccharides (lignin) efficiently and these accumulate and hamper the progress of decomposition (Minderman, 1968; Gourbière, 1982; Toutain, 1987). The acid organic compounds released in the course of decomposition are not flocculated in the presence of mineral particles; they behave as aggressive compounds that may leach and actively participate in the weathering of minerals, thus favouring processes like podzolisation (Berthelin et al., 1979; Pedro, 1989).

Finally, the ecosystem engineers, comprise macrofauna, mainly earthworms and termites, that are large enough to develop mutualistic relationships with microflora inside their gut proper. These interactions may involve obligate (such as the protozoa contained in the posterior pouch of lower termites) or facultative symbionts; the latter occur in the gut of higher termites and also in earthworms (Barois et al., 1987; Breznak, 1984). These organisms usually ingest a mixture of organic and mineral elements. Organic acids produced by digestion, and the subsequent incubation of organic matter in casts, are normally flocculated in the presence of clay minerals and a high microbial 
activity. Digestion is efficient and complex organic compounds like cellulose, lignin and tannin-protein complexes are assimilated (Butler and Buckerfield, 1979; Breznak, 1984; Toutain, 1987; Rouland et al., 1990). Faecal pellets which are large (in the range $0.1-2 \mathrm{~cm}$ and more) may be the component elements of macro-aggregate structures, and participate prominently in the formation of stable structures through the regulation of porosity, aggregation, bulk density and surface features (Bal, 1982). These organisms also build large structures, such as mounds and networks of galleries and chambers, which have significant impacts on the evolution of soils at medium time scales. Ants may be considered as part of this group, although the vast majority of them use soil only as an habitat and have a limited impact on soil organic matter dynamics. They will not be considered in this paper because of the small number of studies devoted to their effects on soil processes.

Whenever conditions are suitable for their activities, macrofauna, and especially earthworms and termites, become major regulators of microbial activities within their sphere of influence (i.e., the termitosphere of termites and the drilosphere of earthworms, Lavelle, 1984) in which they also determine the abundance and activities of smaller groups of soil fauna (Dash et al., 1980; Yeates, 1981). These 'Biological Systems of Regulation' include the rhizosphere in which roots are the major determinant (Lavelle et al., 1993).

The apparent looseness of the soil trophic structure may be due to the juxtaposition of two fundamentally opposite types of relationships between invertebrates and micro-organisms, i.e. (1) a 'classical' foodweb in which organisms of a given size feed on organisms of a lower size, at a lower level in the foodweb, and are eaten by larger organisms which comprise the upper level; and (2) biological systems of regulation (BSRs) which are systems of interactions based on the mutualism between micro-organisms and invertebrates of different sizes.

The overall structure of the foodweb is further complicated by the effect of interactions between BSRs; in some places, for example, favourable conditions may promote high levels of activity of termites or anecic earthworms and, hence, significantly reduce resources available for the development of litter transformers and micropredators.

\section{MICROFAUNA: MICROBIAL REGULATION IN MICRO-FOODWEBS}

\section{A. The Composition of Micro-foodwebs}

Micro-foodwebs are defined as the part of the foodweb that links microorganisms to their predators; they are clearly distinguished from systems organised by litter arthropods and the ecosystems engineers that are based on mutualistic relationships of larger organisms with microflora. 
The soil micropredator foodweb includes micro-organisms, mainly bacteria and fungi, Protozoa, nematodes and some predacious Acarina. Several levels of complexity exist since the system includes microbial grazers, predators and superpredators. Nonetheless, the foodchain length is normally limited to three or four transfers (Moore et al., 1993).

The structure of micro-foodwebs has been established in a number of sites (Hendrix et al., 1986; Elliott et al., 1988; Ingham et al., 1989) and models have been built to simulate the effects of such assemblages on soil processes (Hunt et al., 1987). The composition of foodwebs is largely influenced by the predominance of either fungi or bacteria, which in turn is determined by abiotic factors (Whitford, 1989) and management practices (Hendrix et al., 1986).

Microflora are generally divided into bacteria and fungi, which perform distinct functions and often colonise distinct microsites. Small populations of predatory bacteria and fungi may be found. They are bacterial predators of bacteria, e.g., of the genus Bdellovibrio (Casida, 1988) or nematode-trapping fungi (Cooke and Godfrey, 1964; Mitsui, 1985). Other fungi of the genus Dactylella have been reported to capture and consume amoebae.

Mycophagy by protozoa has rarely been studied quantitatively but the apparent ease with which mycophagous forms are isolated suggests that it is not rare (Petz et al., 1986). They are voracious consumers: a single heterotrophic nanoflagellate may ingest three to nine bacteria per hour and 8300 bacteria are consumed for each new amoeba produced in soil microcosms at $23^{\circ} \mathrm{C}$ (Bloem et al., 1989). Stout and Heal (1967) estimated that Protozoa consume 150-900 g bacteria $\mathrm{m}^{-2}$ year ${ }^{-1}$. Bamforth (1988) distinguishes two kinds of Protozoa: a group which may serve as food for a large variety of organisms and others which are endosymbionts (commensals or parasites). The latter are regularly found in the gut of some termites and earthworms (Astomata) and may have endosymbiotic bacteria in their cytoplasm. Protozoa of the former group are often considered as transformers of bacterial protoplasm into higher trophic levels. Mycophagous amoebae and colpodid ciliates may also ingest fungal spores and thus play a role in the suppression of phytopathogenic fungi and control of fungal populations (Chakraborty et al., 1983; Coûteaux, 1985a).

Nematodes are another constant component of microfoodwebs, at the same level, or one step above Protozoa. A few adult nematodes may actually ingest flagellates and some amoebae (Elliott et al., 1980) although a vast majority are either bacterial- or fungal-feeders. Nematodes are attracted to their food sources through a number of stimuli including pheromones, $\mathrm{CO}_{2}$ and temperature gradients (Freckman, 1988). Bacterial-feeders ingest up to 5000 cells $\mathrm{min}^{-1}$ or 6.5 times their own weight per day. Overall consumption may be as much as $800 \mathrm{~kg}$ bacteria ha $\mathrm{h}^{-1}$ year $^{-1}$ and the amount of nitrogen turned over in the range of $20-130 \mathrm{~kg}$ (review by Coleman et al., 1984). Finally, 
mycophagous nematodes have been reported to suppress plant diseases by ingesting pathogenic fungi (Curl, 1988).

Some components of mesofauna, i.e. Acarina, Collembola and Enchytraeidae, may also be part of micropredator foodwebs, although the majority of them probably rely more on mutualistic relationships than predation (Moore, 1988). Predatory mites can feed on nematodes (e.g., Martikainen and Huhta, 1990). In North American desert systems, they have been reported to regulate nematode density (Whitford, 1989).

The vast majority of macrofauna rely on mutualistic relationships with microflora for their digestion and, hence, do not participate in microfoodwebs. Nevertheless, some degree of predation exists, especially on Protozoa. For example, earthworms can digest ciliates (Piearce and Phillips, 1980) and amoebae (Rouelle, 1983). On the other hand, Protozoa may participate to the function of the external rumen type of digestion in association with earthworms: incubation in faeces results in the excystment and development of protozoan populations which are further digested by invertebrates. In a microcosm experiment, earthworms were introduced into sterilized soil. After 5 days, the density of Protozoa in the soil was $3-70 \times 10^{6} \mathrm{~g}^{-1}$ soil with a predominance of amoebae (Shaw and Pawluk, 1986).

\section{B. Distribution and Dispersal of Microsites}

The activity of soil microfoodwebs mainly occurs in the water-filled soil porespace and water films which cover solid particles. These microsites have a defined distribution in time and space. They depend largely on soil moisture content and porosity, which in turn depend on texture and the overall biological activity. Finally, the presence of carbon resources determines the accumulation of a large microbial biomass which feeds micropredators. In predetermined conditions of substrate availability, the size of pores determines composition of the communities at the microsite level. Flagellates and small amoebae colonize pores of a minimum diameter of $8 \mu \mathrm{m}$; larger Protozoa and nematodes live in larger pores and most nematodes live in the external medium, outside the aggregates (Hattori, 1988). Soil texture and porosity are therefore critical determinants of microfoodwebs. The importance of porosity was demonstrated by an experiment in which bulk density of humus was increased from 0.25 to $0.41 \mathrm{~g}$ $\mathrm{cm}^{-3}$, the abundance of pores larger than $10 \mu \mathrm{m}$ decreased, and growth of ciliates and thecamoebae was inhibited (Coûteaux, 1985b).

The availability of organic resources and transportation of invertebrates across soil microsites are critical to the multiplication of microsites favourable to micropredator foodweb activities. As a result, such microsites are regularly found in the rhizosphere where root growth provides energy for bacteria and their micropredators and the growth of roots consequently disseminates communities in the volume of soil explored by the root system. In 
the presence of guilds of larger invertebrates, microsites may be included in the structures created by these invertebrates, i.e. the termitosphere of termites, or simply disappear.

\section{Evidence for the Functional Importance of Micro- foodwebs: Effects on Soil Organic Matter (SOM) Dynamics}

The functional importance of micro-foodwebs has been demonstrated several times in small-scale laboratory designs or microcosms. Effects on carbon and nutrient cycles have been observed and quantified.

In the carbon (C) cycle, respiration of microfauna only represents a few per cent of overall soil respiration (0.6-2\% for nematodes according to Freckman, 1988). Nonetheless, their effect is disproportionate to their size and they significantly stimulate the growth and turnover of microbial populations, thus promoting faster rates of mineralisation, decomposition and nutrient turnover (Hendrix et al., 1986; Hunt et al., 1987; Sohlenius et al., 1988; Setälä et al., 1990, 1991).

The nitrogen $(\mathrm{N})$ cycle is particularly affected by micro-foodweb interactions since bacteria have $\mathrm{C}: \mathrm{N}$ ratios of $6: 1$ on average, close to that of Protozoa (5:1 according to Reich, 1948, in Stout and Heal, 1967) and slightly inferior to that of nematodes $(10: 1)$. Predation of micro-organisms thus results in the release of mineral- $N$ that may be further used by plants. In the presence of nematodes for example, ammonification by bacteria and nematodes is greatly increased (Ingham et al., 1985). $\mathrm{N}$ fixation may be enhanced through the maintenance of a young population, provision of stimulating compounds or decreased $\mathrm{O}_{2}$ concentration (Darbyshire and Greaves, 1973).

The phosphorus $(\mathrm{P})$ cycle is also affected, although contrasting results have been produced. Coleman et al. (1984a) observed that, in the presence of amoebae, a significant part of $\mathrm{P}$ accumulated in microbial biomass is transformed into bicarbonate-extractable P. Nonetheless, the flux of $\mathrm{P}$ affected by this transformation may be limited; this would explain why few effects on $P$ cycle have been noted, even in microcosms (Baath et al., 1980).

Positive effects of microfoodweb activities on plant growth have been measured in microcosms: when wheat plants were grown in sterilised soil into which both bacteria and Protozoa had been added, their production was increased by $80 \%$ and $\mathrm{N}$ mineralisation from soil organic matter was increased by $59 \%$. In a control soil without plants, no increase in inorganic nitrogen was observed, which emphasises the role of root-derived carbon as a source of energy in the system (Clarholm, 1984). In another 35-day microcosm-reduced experiment, bacterial biomass was eight-fold and $\mathrm{N}$ uptake by plants was increased by $20 \%$ by protozoan activity. In the presence of Protozoa, shoot:root ratio of the plants increased and $65 \%$ more bacterial ${ }^{15} \mathrm{~N}$ was taken up by plants (Kuikman and van Veen, 1989). 


\section{SAPROPHAGOUS ARTHROPODA: THE LITTER TRANSFORMERS}

\section{A. Niche}

Mesofauna and non-social large litter arthropods live in the air-filled pore-space of soil and litter; the smallest live inside the soil in cracks and crevices, the largest in the looser strata of the $A_{0}$ horizon. They are big enough to create distinct structures in which microbial activities are regulated: these are the faecal pellets that accumulate in the litter layers and in the rhizosphere. However, they do not ingest significant amounts of mineral soil and have a limited ability to dig the soil and create galleries or aggregates. The kind of mutualism that they develop with microflora seems to be mostly exhabitational (i.e., in structures created outside the bodies of both components of the association) and no examples of inhabitational mutualist relationships are known.

These invertebrates, which do not possess a proper cellulase, mainly rely on the external rumen type of digestion to digest polysaccharides: they periodically reingest their faeces (or faeces produced by other invertebrates) and thus take advantage of the release of assimilable compounds resulting from microbial incubation (Swift et al., 1979). They comminute, fractionate and moisten the ingested material thereby enhancing microbial activity. Most litter-feeding epigeic arthropods use this digestive system. Macrotermitine termites or ants of the tribe Attini, which cultivate fungi on especially elaborated wood or leaf material, belong to this group, although they also develop inhabitational relationships with microflora. Epigeic earthworms and Mollusca which are restricted to the litter layers also belong to the guild of litter transformers.

\section{B. Structures}

Litter transformers influence soil processes by (1) disseminating fungal spores and mycelium and (2) accumulating faecal pellets which are basic structural units of the holorganic layers $(\mathrm{AH})$ and microsites for enhanced microbial activity.

The size and shape of faecal pellets produced by arthropods are highly variable (Bal, 1982). However, the vast majority of them are small $(<100 \mu \mathrm{m})$ and unstable aggregates made up of untransformed organic matter. They have a low proportion of mineral elements and the rate of decomposition, which is often enhanced in fresh pellets, may be lower in ageing excrements than in the surrounding litter (Reyes and Tiedje, 1976; Hanlon, 1981; Griffiths et al., 1989) due to compaction and accumulation of chemical compounds that are resistant to decomposition. 


\section{Effects on Physical Parameters of Soil}

Litter invertebrates normally ingest small amounts of mineral particles, if any at all. Their contribution to physical soil processes is therefore limited, although some components, such as Enchytraeidae, may occasionally produce intensive burrow systems in selected microsites (Jegen, 1920, in Didden, 1990; Wolters, 1991). They are active agents of fragmentation and transfer of litter material to deeper strata where they accumulate and gradually form the amorphous organic matter of the $\mathrm{H}$ layer. Some groups, however, may ingest significant proportions of mineral elements and play some role in the development of the soil structure. Didden (1990) observed that 21-35\% of the enchytraeids of a Dutch agro-ecosystem contained mineral particles and that the annual transfer of soil due to Enchytraeids amounted to $10-75 \mathrm{~g} \mathrm{~m}^{2}$ of soil of the upper $40 \mathrm{~cm}$, i.e. 0.001 to $0.01 \%$ of the total soil. The proportions of aggregates corresponding to the size of their faecal pellets and of the pores of a size corresponding to their body size, and air permeability were significantly increased. Nonetheless, differences were limited to a few per cent despite favourable experimental conditions (sieved soil and exclusion of other soil fauna components).

\section{SOM Dynamics}

Litter arthropods may ingest litter at different stages of decomposition although they prefer to ingest decayed litter when given a choice (Hassall et al., 1987); Sciaridae (Diptera) which possess cellulase (Deleporte and Rouland, 1991), in contrast to the other arthropods, actively feed on leaves of the L litter layer and assimilate fresh better than previously decomposed material (Deleporte, 1987). Assimilation rates greatly vary among taxonomic groups and also depend on the quality of the litter ingested: they may vary from 9 to $92 \%$ in the Diptera larva Bradysia confinis, although most values are in the range 5-20\% (Petersen and Luxton, 1982). Assimilation rates of different chemical components of litter show great differences: Bocock (1963) stated that the millipede Glomeris marginata utilises 6-10.5\% of the dry matter contained in its food (Fraxinus litter), $43 \%$ of crude fat, $28 \%$ of holocellulose, $29 \%$ of soluble carbohydrates, and $0.3-0.4 \%$ of the nitrogen. Another part of the nitrogen is mineralised and appears as ammonium in faeces.

Microbial communities are modified in faecal pellets as a result of the digestion, compaction and fragmentation of the litter material. In isopod faeces derived from freshly fallen leaves of Betula pendula, densities of fungal and bacterial propagules, respectively, were increased by 3.2 and 126 times (Hassall et al., 1987). Similar effects were observed by Hanlon (1981) with the millipede Glomeris marginata and the isopod Oniscus asellus fed oak litter: bacterial standing crop was multiplied by $c a 10$ and $\mathrm{pH}$ increased from 4.4 to $6.3-6.6$. Differences in the relative response of bacteria and fungi 
appeared to be a result of the compaction of the litter material in faecal pellets: in artificially compacted samples consisting of small particles of litter $(<0.2 \mu \mathrm{m})$ fungal growth was reduced whereas bacterial growth was not changed (Hanlon, 1981). Similar effects occurring in faecal pellets which mainly comprise fine particles would explain this difference.

The introduction of isopods into microcosms containing litter resulted first in a significant increase of $\mathrm{CO}_{2}$ evolution, which was doubled with the optimal number of introduced isopods after 14 days (Hanlon and Anderson, 1980). Microbial respiration then decreased to levels which were still significantly higher than the control after 40 days with optimal numbers of arthropods; in the treatment with a higher density of isopods respiration was lower than in the control. These results suggest that invertebrates promote, in their excrement, an active respiration which is further decreased, possibly owing to changes in the composition of the microflora (decrease of fungal densities) and the compaction of the litter material (Figure 3).

In a comparable study, Hassall et al. (1987) concluded that the overall effect of arthropods on chemical and physical parameters of litter does not necessarily accelerate decomposition very significantly. The major process whereby they accelerate decomposition is the deposition of their faecal pellets into more humid microsites, deeper in the soil profile.

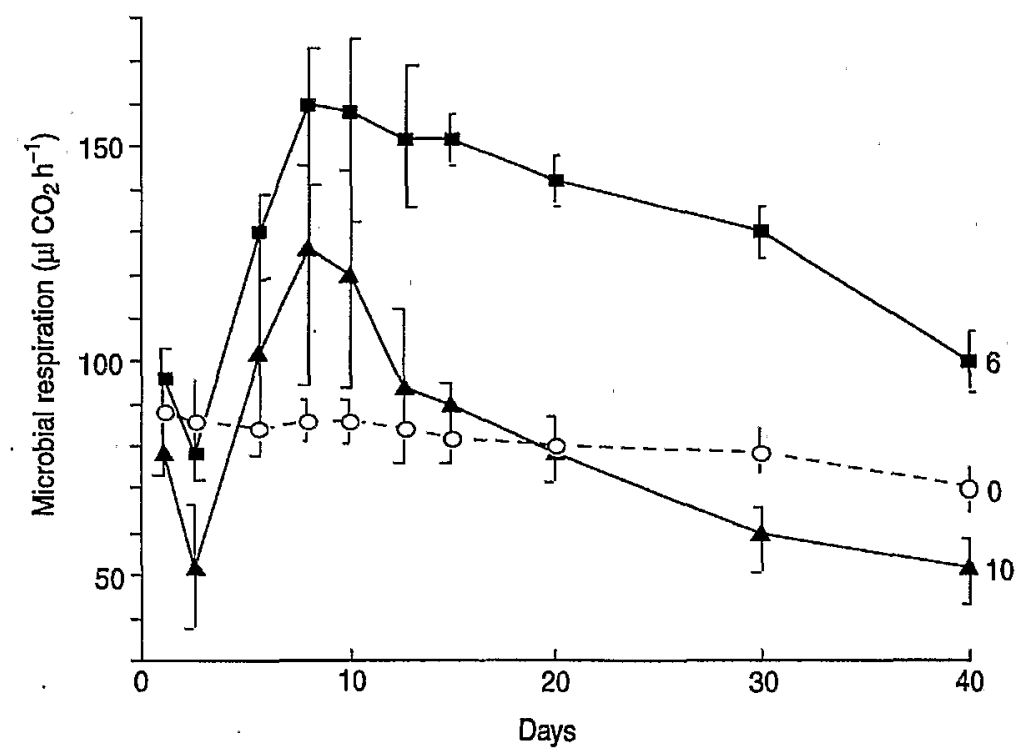

Fig. 3. Effects on microbial respiration of the isopod Oniscus asellus feeding on $1 \mathrm{~g}$ of oak leaf litter in microcosms. 0, 6, 10: number of individuals introduced (Hanlon and Anderson, 1980). 
One major limitation of the guild of litter arthropods seems to be their inability to digest complex tannin-protein compounds which normally block a large proportion of proteins from the cytoplasm of fresh leaves. In such conditions, decomposition of these compounds is slow and only proceeds through weak hydrolyses which slowly unwind the complex phenolic chemical structures of litter (Toutain et al., 1982).

Another major characteristic of litter invertebrate communities is their ability to stimulate nitrogen mineralisation and release ammonium, which may be further nitrified and taken up by plants, or temporarily accumulated before it is lost through volatilisation or immobilised in microbial biomass (Verhoeff and De Goede, 1985). In laboratory experiments, Anderson et al. (1985) established a correlation between the biomass of litter invertebrates and mineral-N release. In a field experiment using microlysimeters, Anderson et al. (1983) showed that during the first 32 weeks, from spring to leaf fall, the activity of soil fauna $\left(13 \mathrm{~g}\right.$ fresh weight $\left.\mathrm{m}^{-2}\right)$ increased the total nitrogen losses by $11.4 \mathrm{~kg} \mathrm{ha}^{-1}\left(5.2 \mathrm{~kg} \mathrm{NO}-\mathrm{N}+6.2 \mathrm{~kg} \mathrm{NH}_{4}-\mathrm{N}\right)$, which represents about one third of the annual nitrogen input through litter. After leaf fall, less mineral- $\mathrm{N}$ was released in the presence than in the absence of fauna. Roots when present, absorbed about half of the mineral nitrogen.

\section{E. Effects on Plant Growth in Microcosms}

Effects of the guild of litter transformers on chemical and physical characteristics of the litter system may have positive effects on plant growth. This effect has been demonstrated several times in laboratory microcosms and larger field designs that simulated conditions of the real forest. Setälä and Huhta (1991) observed significant effects of litter invertebrates on the growth of seedlings of Betula pendula: after two years, leaf, stems and root biomass were, respectively, $70 \%, 53 \%$ and $38 \%$ greater and respective $\mathrm{N}$ and $\mathrm{P}$ contents were 3 and 1.5 times higher.

\section{TERMITES AND EARTHWORMS: THE ECOSYSTEM ENGINEERS}

\section{A. Roles}

Termites and earthworms are major components of the guild of 'ecosystem engineers'. Ants and some large arthropods may to some extent be included in this group. When present, these organisms play a dominant role in the regulation of soil processes because (1) they ingest a mixture of organic and mineral particles and their faecal pellets are large and contain stabilised organic matter; (2) they have efficient symbiotic digestion systems in association with soil microflora which enable them to digest the most complex substrates, i.e. 
tannin-protein complexes, lignin and humic compounds; and (3) they create diverse and abundant structures in soil and hence, have a dramatic effect on the soil physical structure and pedogenesis at different scales of time and space (Figure 4). The abundance and texture of these structures are determined by the consumption rates and selective ingestion of mineral and organic particles. Behavioural characteristics of species, and, to some extent, local edaphic and climatic conditions determine the type of structures created, which in turn affect all soil processes.

\section{B. Effects on Physical Structure}

\section{Selective Ingestion of Particles}

Soil invertebrates often select the particles that they ingest for their size and quality (organic or mineral). The behaviour of endogeic earthworms is highly variable and depends on the species, the size of the individuals and soil type. For example, when kept in an uncompacted, sieved soil in laboratory cultures, the common pantropical species Pontoscolex corethrurus preferentially ingested small, $0-20 \mu \mathrm{m}$, particles in a coarse-textured regosol from Mexico, but coarser particles in a fine-textured ultisol (Barois, 1992 in Lavelle et al., 1992a). There is some evidence that earthworms may select independently for mineral and organic particles and, when given the choice ingest large organic and small mineral particles. However, in a natural soil, endogeic earthworms ingest the soil to feed and move into this compact environment, which does not leave much possibility for a true selection of particles. It is likely that any selection observed results from the selective exploitation of micro-environments and selective behaviours that are still unknown.

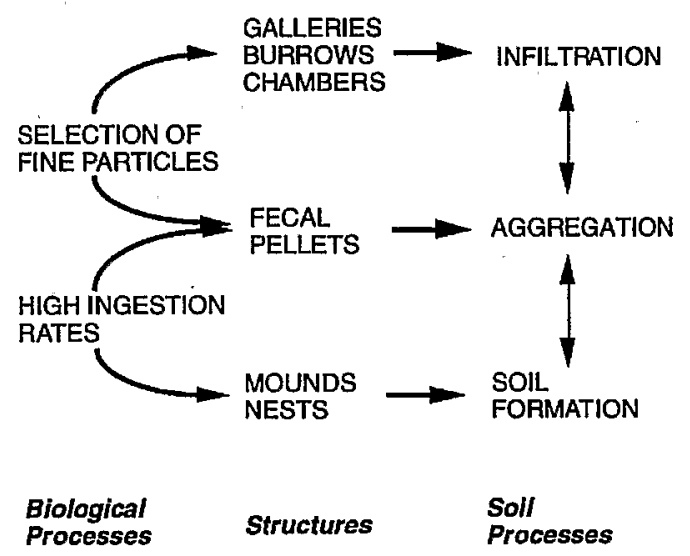

Fig. 4. Effects of macro-invertebrates on soil structure. 
Termite distribution and activity are both affected by, and affect soil texture. The mound building termites are largely excluded from heavy clay, or excessively sandy soils which are not convenient for the building of their nests (Lee and Wood, 1971; Holt and Coventry, 1982). Termites generally select the smaller particles from within the soil profile and bring to the surface significant amounts of clay materials (Williams, 1968; Boyer, 1982). Species-specific effects and variations depending on the soil type have been often mentioned, although a comprehensive understanding of these effects is still lacking (Lee and Wood, 1971; Butler and Buckerfield, 1979; Rajagopal et al., 1982; Spain et al., 1983; Anderson and Wood, 1984; Lòpez-Hernàndez et al., 1984; Garnier-Sillam et al., 1987; Okwakol, 1987; Cox et al., 1989).

\section{Ingestion Rates and Bioturbation}

Earthworms and termites may ingest large amounts of soil and litter, and hence actively participate to the process of bioturbation and become major regulators of the dynamics of litter and SOM in the ecosystem. Anecic earthworm populations, that live in subvertical burrows and feed on a mixture of leaf litter and soil, may incorporate the total annual litter production in as little as 2-3 months when they are abundant (Lee, 1985). Their activity however, is limited by food availability and the environmental determinants of their activity. In a pasture in southern France, Bouché et al. (1983) estimated that earthworms had assimilated $30 \%$ of the carbon available in litter in 17 weeks. Such a figure is only acceptable if earthworms reinvest the litter contained in their casts several times. In regularly burned humid savannahs in the Cote d'Ivoire, anecic earthworms incorporate $180-510 \mathrm{~kg}$ of dry litter to the soil annually. This represents $c a 30 \%$ of the weight of litter annually decomposed (i.e. mineralised or incorporated into the soil instead of being destroyed by fire), but less than $10 \%$ of the annual production (Lavelle, 1978). Endogeic earthworms which mainly feed on soil from the $A_{1}$ horizon, and anecic species which ingest a mixture of soil and 20-50\% litter (Bouché and Kretzschmar, 1974) may annually ingest several hundred tonnes of dry soil per ha (Lavelle, 1978; Lee, 1985). A maximum value of $1250 \mathrm{Mg} \mathrm{ha}^{-1}$ year $^{-1}$ has been measured in humid savannahs at Lamto (Côte d'Ivoire) where this soil is normally taken from the upper $10 \mathrm{~cm}$ of soil; some species, however, particularly in the humid tropics, specialise in the ingestion of soil from the deep $(20-50 \mathrm{~cm})$ horizons of soils. Most of this soil is egested inside the soil profile: in the humid savannahs of Lamto (Côte d'Ivoire), 3 to 18\% of the soil is egested as surface casts, depending on the species (Lavelle, 1978).

Termites may also ingest significant amounts of litter and soil: in low-lying parts of Sahelian grasslands of Sénégal, they may consume up to $49 \%$ of annual herbage production and in semiarid pastures of Kenya, they have a similar impact to grazing mammals with an annual consumption estimated at 
$1 \mathrm{Mg} \mathrm{ha}^{-1}$ (Lepage, 1974, 1981). Several estimates indicate rates of consumption in the range $1-16 \%$ of annual primary production in tropical forests and savannahs (Lee and Wood, 1971; Collins, 1983). Soil brought to the surface in surface nests and sheathings may represent up to $2400 \mathrm{Mg} \mathrm{ha}^{-1}$ and cover $10 \%$ of the soil surface (Meyer, 1960).

\section{Structures}

Macro-invertebrate activities create three types of structures: nests and chambers that host individuals or parts of a society; casts which may be deposited at the soil surface or inside the profile; and voids, pores and galleries that result from the movements of the invertebrates in soil or at the surface (like surface galleries of termites).

Nests may be compact and somewhat complex structures made of selected materials and/or faecal pellets; they may remain intact for several decades (as long as the colony is alive). At the death of the colony, they start to decay. This is a slow process that may leave visible mounds, often representing islands of soils with a relatively high fertility on which the density of trees is high (Lavelle et al., 1992c). Some termites and ants may have diffuse nests made of small subterranean chambers of a few centimetres connected by a dense network of galleries. Termites also produce surface sheathings which cover the soil and litter when they go foraging.

Earthworms produce large amounts of casts; the majority are round-shaped and compact structures which are isolated from the rest of the soil by a thin cortex of clay minerals and organic colloids (Blanchart et al., 1993). Their size and shape depend on the size of the species, the soil texture and feeding habits of the species. Lee (1985) thus distinguish globular casts made of the fusion of oval-shaped pellets one to several millimetres in diameter into 'paste-like slurries', and granular casts made of an accumulation of small and fragile fine-textured pellets.

Galleries are a frequent product of activities of the 'ecosystem engineers': they may be subhorizontal and connect chambers of a nest, or subvertical and connect deep soil horizons (where anecic earthworms find suitable conditions of temperature and moisture, out of the reach of predators) to the surface, where they come at night to ingest litter. Endogeic geophagous earthworms also dig subhorizontal galleries that they immediately refill with their casts as they eat their way through the soil. Gallery networks may be extremely dense: in temperate pastures in France, Kretzschmar (1982) found 4000-29 800 galleries $\mathrm{m}^{-2}$ with a total length of $142-890 \mathrm{~mm}^{-2}$ depending on the season. $16.3 \%$ of these galleries were found deeper than $60 \mathrm{~cm}$ depth and the overall surface of gallery walls was $1.6-12 \mathrm{~m}^{2} \mathrm{~m}^{-2}$. In a large survey in several regions of France, Lopes-Assad (1987) examined 24 different soil profiles and found 60-290 active (i.e., opened to the surface) galleries $\mathrm{m}^{-2}$; their total length 
ranged from 6.2 to $66.6 \mathrm{~m} \mathrm{~m}^{-2}$ and they comprised $\mathrm{ca} 0.6 \%$ of the total volume of soil. Galleries are cylindrical and their walls are regularly coated with cutaneous mucus each time that the worm passes through. Cast deposits and iron oxide depositions are regular features of these galleries (Jeanson, 1979; Kretzschmar, 1987; Lamparski et al., 1987).

Termites may also dig extensive networks of galleries; the diameter of termite galleries is in the range $1-20 \mathrm{~mm}$ and their networks may comprise up to $7.5 \mathrm{~km} \mathrm{ha}^{-1}$ (Darlington, 1982; Grassé, 1984; MacKay et al., 1985, 1988; Wood, 1988). Some Macrotermitinae may open holes at the surface to use to go foraging at night; the overall surface of these openings has been estimated at $2-4 \mathrm{~m}^{2} \mathrm{ha}^{-1}$ (Lepage, 1981).

\section{Effects on Soil Physical Parameters and Pedogenesis}

The activities of earthworms and termites mainly affect surface roughness, porosity and aggregation with significant effects on hydraulic properties of soil, especially rates of water infiltration.

Infiltration of water and gases. Termite galleries and earthworm burrows have a significant effect on water infiltration despite their low contribution $(<1 \%)$ to the soil volume (see review by Lee, 1985; for earthworms, Lepage, 1979). Experiments in arable land have demonstrated that when directdrilling is substituted for ploughing, anecic earthworms are favoured. As a result of their enhanced activities, hydraulic conductivity at the interface between A and B horizons may be doubled (Urbanek and Dolezal, 1992). In West Africa, Casenave and Valentin (1988) found a significant relationship between the presence of earthworm casts and termite sheathings and water infiltration rates: infiltration increased with the percentage of soil covered by earthworm casts and termite sheathings and maximum values were obtained when more than $20 \%$ and $30 \%$ of the soil surface were covered with earthworm casts and termite sheathings, respectively. Kladivko et al. (1986) also concluded that earthworms could diminish surface crusting.

The increase of infiltration stems mainly from water retention owing to an increase of surface roughness and the presence of macropores and galleries below surface structures. Similar effects have been mentioned by several authors (Lal, 1988; Aina, 1984; Lavelle, 1992a; review by Lee, 1985). However, species-specific effects on water infiltration have been observed in earthworms: In pot experiments at Lamto (Côte d'Ivoire), Derouard et al. (1996) clearly distinguished species which compact the soil and decrease infiltration rates (e.g., Millsonia anomala) and species which decompact the soil and increase water infiltration (Hyperiodrilus africanus and Chuniodrilus zielae) whereas associations of species might give intermediate results (Figure 5). In the same experiment, there was evidence that the effect of earthworms on soil physical parameters might change, depending on the plant that 
was present in the experimental unit: under similar experimental conditions soil compaction and surface crusting were maximum in pots cropped to rice (Oriza sativa) and minimum in pots with peanut (Arachis).

Gas diffusion is affected in the same way as water infiltration, although diffusion around galleries is more important than direct diffusion along the burrows (Kretzschmar, 1989).

Similar effects have been observed with termites and their exclusion from the soil of a North American desert significantly increased the bulk density of soil and erosion while water infiltration was decreased (Elkins et al., 1986).

Porosity. Earthworms and termites generally contribute to the maintenance of a relatively high porosity by digging galleries. Deposition of earthworm casts at the soil surface is a mechanism that regulates soil porosity, as a volume of voids equivalent to that of casts is created inside the soil. This may represent volumes of tens of $\mathrm{m}^{3}$ of voids $\mathrm{ha}^{-1}$ year-1 which preferably are created at times and in sites where compaction is occurring. Seasonal variations of soil porosity have been sometimes related to variations of the abundance of earthworm populations (Hopp, 1973). Correlations between soil porosity and colonisation of new soils by earthworms always results in a significant increase of porosity which may be doubled (Hoeksema and Jongerius, 1959).

Oryza sativa
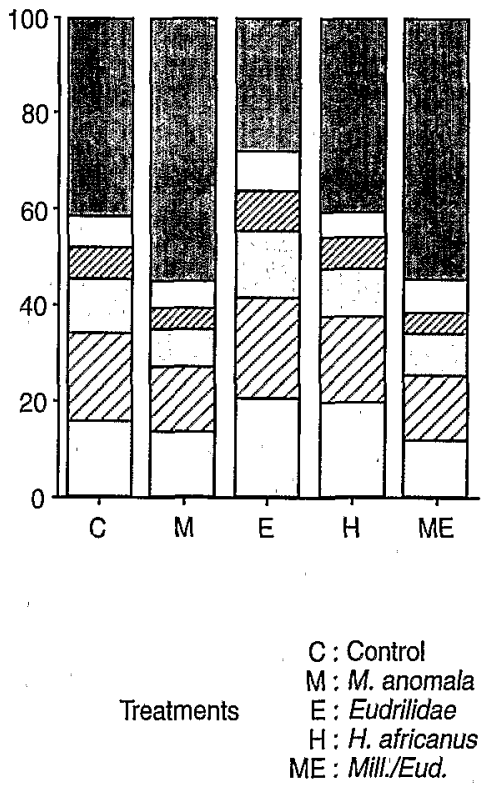

Arachis

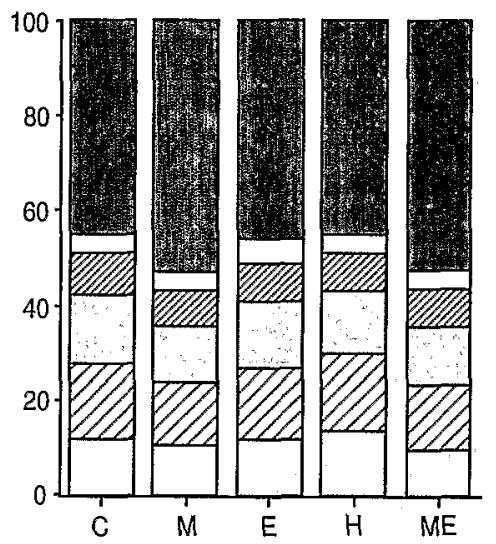

$>5 \mathrm{~mm}$

$$
\begin{aligned}
& \square 5-2 \mathrm{~mm} \\
& \square 2-1 \mathrm{~mm} \\
& \square 1-0.5 \mathrm{~mm} \\
& \square 0.5-0.25 \mathrm{~mm} \\
& \square<0.25 \mathrm{~mm}
\end{aligned}
$$

Fig. 5. Effect of different earthworm species or assemblages of species on the aggregation of a savanna alfisol in pot experiments over 80 days (Derouard, 1993). Blocks of a same category with different letters are significantly different $(P<0.05)$. Control with plant but no worms 
Soil aggregation. Endogeic earthworms especially affect the soil structure by promoting macro aggregation, i.e. the combination of soil particles into stable compound structures larger than $2 \mathrm{~mm}$ diameter. These earthworms may annually ingest between a few hundreds to more than $1000 \mathrm{Mg}$ dry soil $\mathrm{ha}^{-1}$ (Lavelle, 1978). In four arable soils with unfertilised and fertilised barley, a grass plot and a lucerne layer, the annual cast production of Aporrectodea caliginosa was estimated at $36-108 \mathrm{Mg} \mathrm{ha}^{-1}$, of which $20-50 \%$ was deposited at the soil surface. In humid tropical grasslands, endogeic earthworms may ingest daily 5-6 (Pontoscolex corethrurus) and up to 25-30 (Millsonia anomala) times their own weight of soil (Lavelle, 1978; Lavelle et al., 1987). As a result, the overall annual production of casts may be as high as several hundreds, and up to $1250 \mathrm{Mg} \mathrm{ha}^{-1}$. A small proportion of these is deposited at the soil surface and subterranean casts are the component units of stable macroaggregate structures.

Experiments have demonstrated that such structures may be built in surprisingly short periods of time, thus pointing to the fact that factors other than the simple production of globular casts participate in aggregation (Blanchart et al., 1989): in 33 days, the activity of $5 \mathrm{~g}$ of Millsonia anomala resulted in the formation of $2883 \mathrm{~g}$ of aggregates (i.e., $42.4 \%$ of the soil in the experimental container), compared with $906 \mathrm{~g}(13.3 \%)$ in a control treatment and $1075 \mathrm{~g}(15.8 \%)$ in a treatment with a plant, the grass Panicum maximum. Production of casts by the earthworms was estimated at $1815 \mathrm{~g}$, i.e. $63 \%$ of the aggregates formed; the remaining $37 \%$ might be due to proliferation of fungal hyphae.

When earthworms were excluded from a soil in which they had built a macro-aggregate structure, this structure remained stable for a long time (at least several years) due to the stabilisation of aggregates with time. However, the introduction of earthworms producing granular casts causes destruction of the structure as large aggregates are split into much smaller and fragile ones (Blanchart et al., 1996) As a result, there is a regulation of soil aggregation with small earthworms breaking large aggregates and thus preventing an excessive accumulation of large compact aggregates which otherwise may negatively affect plant growth (Rose and Wood, 1980).

Faecal pellets of some termites are organomineral micro-aggregates (Garnier-Sillam et al., 1987) which form the walls of termite mounds and even surface soil horizons of some tropical soils (Wielemaker, 1984; Eschenbrenner, 1986). These effects are largely dependent on adaptive strategies of species and more information is required before a comprehensive understanding of these processes is available.

Long-term effects of invertebrates on pedogenesis have not yet been comprehensively considered and studies that specifically address this issue are needed. A few studies have indicated that termites and earthworms may be significant determinants of pedogenetic processes in the upper $30-60 \mathrm{~cm}$ of soils 
(Lee and Wood, 1971; Pop and Postolache, 1987). Vermic soils with high earthworm activity have been recognised as a separate entity in the USDA "7th approximation'. Pop and Postolache (1987) state that 'by definition, a normally developed soil must be vermic (because) when defining mull, Kubiena states 'Practically all aggregates are earthworm casts or residues of them'. There is also some evidence that termites may influence pedogenesis in deeper soil strata but more studies are needed (Wielemaker, 1984; Eschenbrenner, 1986).

\section{Effects on SOM dynamics}

\section{Digestion of SOM: Importance of Priming Effects}

Termites and earthworms have highly efficient digestion systems which allow them to digest woody material or live on the highly dispersed and lowquality soil organic matter.

Earthworms digest soil organic matter with enzymes that are produced partly by the worm itself and partly through a mutualist association with the ingested microflora. They add $80-120 \%$ water to the ingested soil and 5-38\% of the dry weight of soil as mucus, a readily assimilable substrate that they energetically mix in the anterior part of the gut. The addition of mucus to the soil triggers a priming effect (sensu Jenkinson, 1966) on soil organic carbon: microbial activity is greatly enhanced. Although the earthworm is able to produce some of the enzymes that are found in the gut content, such important enzymes as cellulase and mannanase (which degrades an important component of root material) are actually released by micro-organisms in the gut lumen (Zhang et al., 1993). In the second part of the gut, when mucus has disappeared, micro-organisms digest soil organic matter and digestion products are then partly absorbed by the worm (Barois and Lavelle, 1986; Martin et al., 1987; Trigo and Lavelle, 1992; Lavelle and Gilot, 1994).

Priming effects have not been described in the gut of termites. These insects seem to be able to produce a large variety of enzymes which interact with enzymes produced by the associated microflora to digest cellulose, lignin and other components of SOM (see, e.g. Rouland et al., 1988, 1991). Some termites have protozoan symbionts whereas fungus growers rely on a mixture of inhabitational mutualism with microflora in their gut, and an external rumen with fungi cultivated in fungus gardens. Assimilation rates in the termites are high and published values range between $54 \%$ and $93 \%$ of the food eaten (Wood, 1978). Endogeic earthworms which feed on soil organic matter may live on soils with only $1 \%$ organic matter with assimilation rates of a few per cent (Martin and Lavelle, 1992).

\section{Short- and Long-term Effects}

Earthworms and termites have contrasting effects on SOM dynamics depending on the scale (Figure 6). 


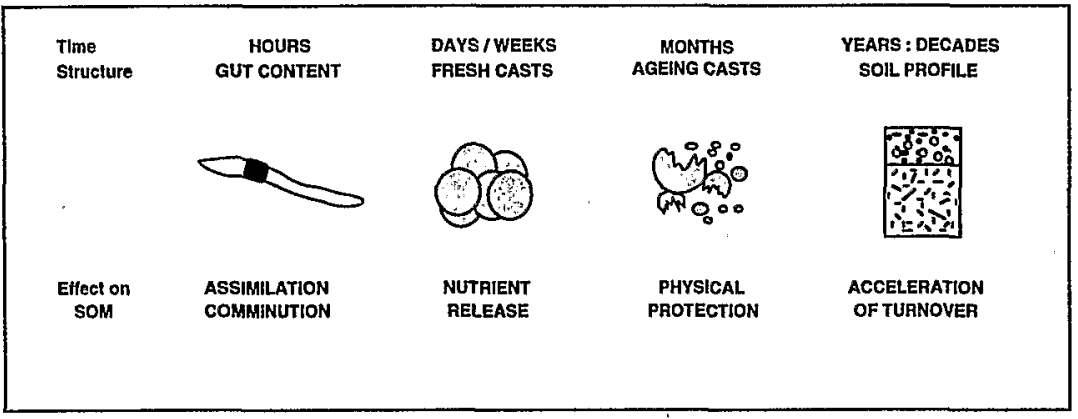

Fig. 6. Effects of earthworms on SOM (soil organic matter) dynamics at different scales of time and space.

At the short scale (hours and $\mathrm{mg}$ to cg of soil) of a gut transit, mineralisation of SOM is strongly increased. In a few hours (and even $30 \mathrm{~min}$ in the case of some tropical earthworms) part of the ingested SOM will have been assimilated. Detailed studies on temperate and tropical earthworms with bomb radiocarbon and natural ${ }^{13} \mathrm{C}$ labelling demonstrate that they mostly assimilate young organic matter from the labile fractions (Scharpenseel et al., 1989). However, Millsonia anomala, an endogeic African earthworm is able to digest all particle-size fractions of a savannah alfisol with the same efficiency, which would mean that they are able to digest some resistant organic matter (Martin et al., 1991). Earthworm digestion results in the fragmentation of the ingested organic debris and the release of significant amounts of mineral nitrogen and phosphorus (Sharpley and Syers, 1976; Barois et al., 1987; Lavelle et al., 1992b). The ability of earthworms to release mineral $\mathrm{N}$ and $\mathrm{P}$ from resources with high C:N and C:P ratios is a result of (1) their high efficiency at digesting compounds - that they excrete as intestinal and cutaneous mucus - which leaves nutrients in excess; (2) the rapid turnover of nitrogen in biomass (Ferrière and Bouché, 1985; Barois et al., 1987; Cortez et al., 1989), and (3) the continuation of mineralisation for some hours in freshly deposited casts resulting from enhanced microbial activity. Effects on phosphorus are especially interesting since part of the pool which is normally adsorbed in soil may be desorbed after a transit through earthworm guts (Lopez-Hernandez et al., 1993; Brossard et al., 1996). Estimates of the overall release of assimilable $\mathrm{N}$ range from 25 to $150 \mathrm{~kg}$ mineral $\mathrm{N} \mathrm{ha}^{-1}$ in tropical grasslands (Barois et al., 1987; Lavelle et al., 1992b) whereas Brossard et al. (1996) estimated the amount of mineral-P-released in a vertisol in Martinique covered with pasture at $50 \mathrm{~kg} \mathrm{ha}^{-1}$.

Although termites have a highly efficient digestion, they do not appear to release important amounts of assimilable nutrients in their faeces. They have 
developed highly efficient mechanisms for $\mathrm{N}$ conservation, and $\mathrm{N}$-fixing organisms have been found in their guts as in the guts of earthworms (Breznak, 1984). Another specific feature of their digestion is the release of methane by humivorous and, to a lesser extent, xylophagous, and fungusgrowing termites.

At the scale of days to months, earthworms and termites affect the dynamics of SOM in the structures that they have created: in earthworm casts, mineralisation rates rapidly decrease after a few days following their deposition. In casts of Millsonia anomala fed with a poor sandy alfisol, concentrations of $\mathrm{NH}_{4}-\mathrm{N}$ in casts decrease to control levels after 8 days (Lavelle et al., 1992b). In casts of European Lumbricidae (Syers et al., 1979) and the pantropical species $P$. corethrurus fed with richer soils (Lavelle et al., 1992b), the amount of $\mathrm{NH}_{4}-\mathrm{N}$ and $\mathrm{NO}-\mathrm{N}$ is still higher than in the control 2 weeks after the deposition of casts. Over a longer period, mineralisation is inhibited in the compact structure of casts and, after 1 year of incubation at field capacity and $28^{\circ} \mathrm{C}$, the decomposition rate in casts of $M$. anomala was three times lower than in a control soil sieved at $2 \mathrm{~mm}$. Interestingly, there was clear evidence in this experiment that the coarse organic fractions had been significantly protected from decomposition whereas the decomposition of the finest fractions was increased (Martin, 1991). Termites also have significant effects on the release of mineral- $\mathrm{N}$ in the structures that they create. The walls of chambers of fungus gardens of Trinervitermes geminatus have much higher potentials for $\mathrm{N}$-mineralisation than the bulk soil in short-term incubations (Abbadie and Lepage, 1989).

In the long term, i.e. from a few years to decades, the overall effect of earthworms and termites is still uncertain because there are few long term experiments. In 3-year field experiments comparing low-input agricultural systems with and without earthworms, differences between treatments were limited: the introduction of earthworms had not impeded the rapid loss of organic matter following the conversion to annual cultures, and only slight differences were seen in the proportion of different particle size fractions (Gilot, 1994; Pashanasi et al., 1996). However, after the fifth crop at Yurimaguas (Peruvian Amazonia), soil organic content decreased more slowly in earthworm treatments and a significant protection of SOM started to be apparent. In a similar experiment conducted at Lamto (Côte d'Ivoire) there was no evidence of a better conservation of SOM due to the presence of earthworms. However, the quality of SOM had changed because standard laboratory tests indicated that $\mathrm{CO}_{2}$ evolution was significantly higher in the earthworm treatment than in the control. There are, therefore, some indications that the presence of earthworms may limit the losses of organic matter in disturbed systems such as annual crops and modify the quality of SOM by operating a relative protection of young organic matter and facilitating the assimilation of part of the old resistant organic matter. Long-term experiments 
based on natural ${ }^{13} \mathrm{C}$ labelling of organic matter will allow this hypothesis to be tested. It is likely that the effect of earthworms will depend in the end on a hierarchy of factors including soil characteristics (especially clay mineralogy and abundance), the quality and quantity of organic inputs and last, but not least, species-specific effects. The diet of earthworms and the shape and structure of their casts will probably be critical criteria to consider when looking for a comprehensive explanation of the process involved.

In the long-term, termites tend to accumulate the undigested organic matter of their faeces in the walls of termitaria; they are conserved as organomineral compounds which resist decomposition. This is, for example, the case for the humivorous termites of the species Thoracotermes macrothorax, a dominant species in the Mayombe forest in Congo (Garnier Sillam et al., 1991) Generally, the organic matter content of walls of the termitaria may be up to $50 \%$ greater than in the surrounding soil. This organic matter has a low C:N ratio and forms stable complexes with clay minerals (Lee and Wood, 1971; Arshad and Schnitzer, 1987; Garnier-Sillam et al., 1987; Okwakol, 1987). Some fungus-growing termites such as Macrotermes mulleri do not incorporate their faeces to the walls of their termitaria and, consequently, the walls have lower contents in organic matter than the surrounding soil. These termites do not appear to play any role in the long-term conservation of soil organic matter in the ecosystem (Garnier-Sillam et al., 1987).

\section{Effects on Plant Growth}

The effects of macro-invertebrates on soil processes, at different scales of time and space, may considerably affect soil fertility and, ultimately, result in dramatic changes of plant growth. Small-scale experiments have given somewhat variable results owing to species-specific effects and large-scale field experiments are still scarce.

The effect of termites on plant growth and production is still largely ignored. An abundant literature describes the negative effects of termites on crops and wood products and the ways to get rid of them (Harris, 1969; Vinson, 1986; Cowie et al., 1991; Kumarasinghe, 1991; Rajagopal et al., 1991). Indirect effects via the modification of soil processes induced by termite activities do not appear to have been evaluated. Experiments have demonstrated that soil from the walls of nests of Amitermes laurensis may be much better for plant growth than the surrounding soil (Okello-Oloya and Spain, 1986). This effect was significant with soil taken within $1 \mathrm{~m}$ from the termite mound and at a depth of up to $50 \mathrm{~cm}$. This effect has long been recognised by indigenous populations and the use of soil from some termitaria as fertiliser is not an uncommon practice (e.g., Swift et al., 1989). However, no comprehensive scientific study has ever evaluated this practice in the general context of a farming system. 
The effects of earthworms on plant growth have been well documented, especially in short-term pot experiments. Most studies indicate clearly positive effects on plant growth (Stockdill, 1959, 1982; Rose and Wood, 1980; Hoogerkamp et al., 1983; Lee, 1985; Senapati et al., 1985a; Curry and Boyle, 1987; Tomati et al., 1988; Buse, 1990; Galli et al., 1990; Clements et al., 1991; Haimi et al., 1992; Pashanasi et al., 1992; Spain et al., 1992 for a complete review). Nonetheless, there is some evidence that not all plants respond equally to the activities of earthworms of a given species: Pashanasi et al., (1992) observed a 14-24-fold increase of biomass of seedlings of the tree Bixa orellana in 120-day pot experiment after the inoculation of Pontoscolex corethrurus, whereas the growth of Eugenia stipitata seedlings was increased only 1.6-2.5-fold and that of the palm-tree Bactris gasipaes was 1.8-2.7 lower. A likely explanation was that Bixa, having a dense root system made of fine roots, was much more receptive to earthworm activities than the little developed and coarse root system of Bactris. Other pot experiments have demonstrated that the effect of earthworms may considerably vary depending on the species used and biomass. Some combinations of earthworm and plant species may give negative results and an excessive, or insufficient biomass may also have zero or negative effects on plant growth (Derouard et al., 1996). Plants produced in the presence of earthworms may have higher nutrient contents (Spain et al., 1992).

Larger-scale field experiments have confirmed these observations, although these effects tend to be much lower owing to limitation of earthworm activities by climatic factors or organic resources provided by soils. Conversely, the introduction of earthworms may sometimes trigger a flush of activity which may not be sustained for a long time if the increase of production does not result in an increased ability of the soil to sustain large populations.

Introduction of earthworms in ecosystems which did not have them, or that were colonised by an inefficient population often gives spectacular results (Hoogerkamp et al., 1983). In New Zealand, the replacement of native grasses by European species resulted in better production but a thick mat of slowly decomposing litter accumulated at the surface. The introduction of European Lumbricidae accelerated the incorporation of litter to soil and pasture production was further improved (Stockdill, 1959; 1982). The introduction of earthworms is currently used in projects of land reclamation or creation of new soils as, for example, in polders (Hoogerkamp et al., 1983; Marinissen and van den Bosche, 1992).

Experiments have been carried out to test the effect of inoculation of earthworms in tropical soils from Mexico, Peru and Côte d'Ivoire submitted to slash-and-burn low-input agriculture (Barois et al., in Lavelle et al., 1992; Gilot, 1994; Pashanasi et al., 1996). Soils under that type of management generally have very small populations due to the lack of adaptable populations. A significant correlation was observed between the increase in plant production and earthworm biomass (Figure 7). 


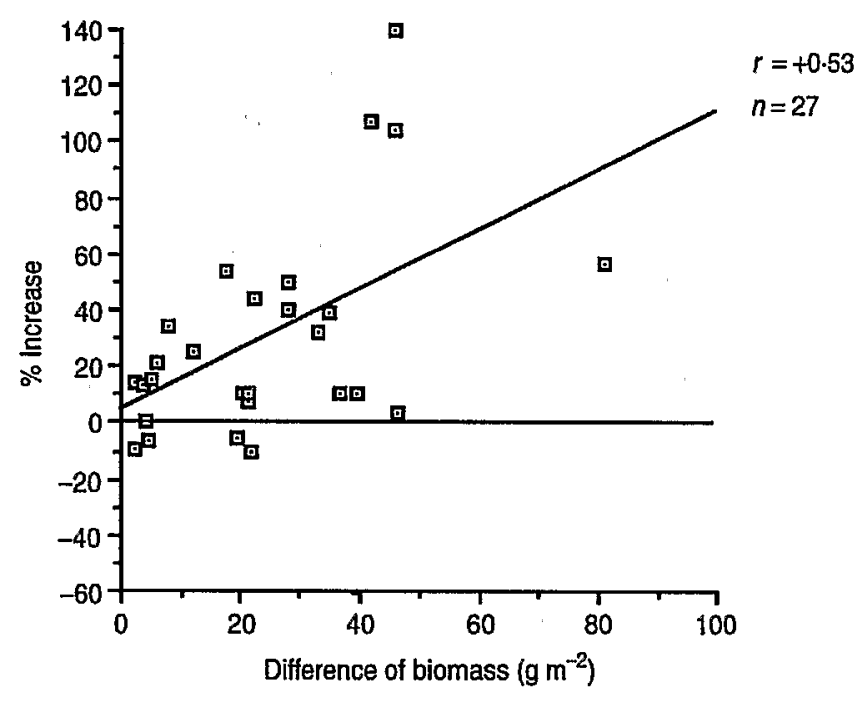

Fig. 7. Relationship between the difference of earthworm biomass measured between a control and a plot inoculated with earthworms and the increase of grain production (maize or rice) in field experiments carried out at three sites of the humid tropics (Lavelle and Gilot, 1993), each point represents one crop.

The major limitation to earthworm biomass was the ability of the system to provide fresh organic matter to feed the worms. The addition to the soil of organic residues which are normally not used in farming systems is envisaged as a means to increase earthworm biomass; coir, sawdust, coffee residues might be used for that purpose (Lavelle et al., 1993).

The mechanisms whereby earthworms stimulate plant growth are still unclear. They are certainly manifold and include (1) mobilisation of nutrient pools that normally are not available (e.g., adsorbed phosphorus and nutrients contained in resistant organic fractions); (2) favourable changes in water and oxygen supply to roots; (3) more efficient use of nutrients based on an improved synchronisation and juxtaposition of nutrient release and nutrient uptake by plants (Swift, 1986; van Noordwig and De Willigen, 1986); and (4) a 'hormone-like' effect of earthworms (Tomati et al., 1988). In experiments where ${ }^{15} \mathrm{~N}$-labelled plant material or microbial biomass had been added, the recovery of ${ }^{15} \mathrm{~N}$ in plant biomass is always improved in the presence of earthworms (Lavelle et al., 1992a; Spain et al., 1992).

\section{CONCLUSIONS}

Significant advances have been made in the understanding of the role of soil fauna in soil function. Their relation to soil fertility is better understood 
although several detailed mechanisms are still unclear. It is now possible to revisit a few old questions and myths of soil science regarding soil zoology and propose novel research avenues.

Do the soil fauna create fertility, or is it fertility that sustains faunal communities? There is now clear evidence that faunal activities contribute to soil fertility since they play a large role in the transformations of soil organic matter and nutrients, at different scales of time and space, which influences their turnover and conservation, and probably improves the efficiency of the use of nutrients by plants. Digestive processes and physical structures created by soil invertebrates contribute significantly to these improvements. However, mechanical activities necessary to these processes have a cost in terms of carbon that the ecosystem must be able to provide. Faunal activities consume carbon whereas nutrients are only temporarily immobilised in their biomass. In humid savannahs of Côte d'Ivoire at Lamto, for example, earthworms which annually turn over $c a 1000 \mathrm{Mg}$ dry soil ha ${ }^{-1}$ annually assimilate $1.2 \mathrm{Mg}$ $\mathrm{ha}^{-1}$ of soil organic matter containing some $700 \mathrm{~kg}$ carbon, of which $96 \%$ is used for maintenance and mechanical activities. Studies on soil fertility and sustainable use often put a major emphasis on nutrient cycling and stocks. Our synthesis supports the commonly accepted idea that SOM is the key element to sustain fertility; however, more attention should be paid specifically to the energetic role of SOM, which is poorly addressed. An optimised production (or importation) and allocation of $\mathrm{C}$ should be considered as an important objective, as much as nutrient supply and conservation of the soil structure. This might prevent cultivated soils having such deficient faunal activities, as is usually observed, and would probably improve the sustainability of their use. Carbon budgets should be considered at relatively large scales, from the watershed catchment (in which 'parcels' of different shapes with different treatments may interact, and exchange carbon and fauna), or region where transfers of carbon residues may be operated, to the farming system such as using sawdust or coir produced from industrial settlements to low-input agriculture. These include an accurate evaluation of the quantity and quality of the organic matter produced, the allocation of carbon and nutrients from this source to soil biota and the different compartments of soil organic matter

The contribution of soil invertebrates to pedogenesis. The role of biological processes in pedogenesis has rarely been directly addressed. The role of organic acids released by litter transformers in their faecal pellets, and the impact of the structures built - and transfers of elements operated by - large invertebrates (ecosystem engineers) should be quantified and incorporated into models of soil formation. This is particularly true of tropical soils in which termite and earthworm activities may have considerable impact on soil formation through bioturbation and the transit of enormous amounts of soil through the gut. Intestines of macro-invertebrates are powerful microbial and 
chemical reactors in which unexpected modifications of minerals and organomineral compounds are likely to occur. Changes in the crystallisation of clay minerals and desorption of $\mathrm{P}$ from resistant pools are examples of processes that are suspected to occur (Boyer, 1982; Lopez-Hernandez et al., 1993; Brossard et al., 1996).

Reaction to human activities and global environmental changes. Soil invertebrates should be considered as a resource that is highly sensitive to human impacts. High-input agriculture based on annual crops has a measurably negative impact on their communities through mechanical disturbance, depletion of assimilable carbon and non-target effects of chemicals. Attention should be paid to conserve biodiversity of soil invertebrates and assess the impact of land-use practices on their spatial distributions, at different scales, from that of a parcel to that of a watershed catchment and regional and biogeographical scales. Dynamics of communities during agricultural rotations or long-term disturbances is not known. Because of specific biogeographical features and slow rates of colonisation, the most efficient species in terms of stimulation of plant growth and soil conservation are not always present everywhere. This is especially true when human intervention creates novel ecosystems, such as a grassland in the middle of an old rainforest, or a fertilised pasture with high-quality grasses in a land that was always covered with low-quality grasses adapted to nutrient deficiencies. Under such circumstances, the management of soil fauna should be considered; pioneering introductions of European earthworms in New Zealand indicate that it is both feasible and useful. At a smaller scale, attention should be paid to the impact of the shape and relative localisation of parcels dedicated to different uses on the conservation and colonisation of soil fauna populations.

\section{REFERENCES}

Abbadie, L. and Lepage, M. (1989). The role of subterranean fungus comb chambers (Isoptera, Macrotermitinae) in soil nitrogen cycling in a preforest savannah (Côte d'Ivoire). Soil Biol. Biochem, 21 (8), 1067-1071.

Aina, P. O. (1984). Contribution of earthworms to porosity and water infiltration in a tropical soil under forest and long-term cultivation. Pedobiologia 26, 131-136.

Anderson, J. M. (1987). Interactions between invertebrates and microorganisms: noise or necessity for soil processes? In: Ecology of Microbial Communities, pp. 125-145. Cambridge University Press, Cambridge, UK.

Anderson J. M. and Flanagan P. (1989). Biological processes regulating organic matter dynamics in tropical soils. In: Dynamics of Soil Organic Matter in Tropical Ecosystems (Ed by T. Oades, G. Uheara and D.C. Coleman), pp. 97-125. NifTAL project, Univ. of Hawaii., Honolulu.

Anderson, J. M. and Wood, T. G. (1984). Mound composition and soil modification by two soil feeding termites (Termitinae, Termitidae) in a riparian Nigerian forest. Pedobiologia 26, 77-82. 
Anderson J. M., Ineson, P. and Huish, S. A. (1983). The effects of animal feeding activities on element release from deciduous forest litter and soil organic matter. In: New Trends in Soil Zoology. (Ed. by Ph. Lebrun et al.), pp. 87-100. Dieu-Brichart, Ottignies-Louvain-la-Neuve, Belgium.

Anderson, J. M., Leonard, M. A., Ineson, P. and Huish, S. (1985). Faunal biomass: a key component of a general model of nitrogen mineralization. Soil Biol. Biochem. 17 (5), 735-737.

Andren, O., Lindberg, T., Boström, U., Clarholm, M., Hansson, A.C., Johansson, G., Lagerlöf, J., Paustian, K., Persson, J., Pettersson, R., Schnürer, J., Sohlenius, B. and Wivstad, M.A. (1990). 5. Organic carbon and nitrogen flows In: Ecology of Arable Land-Organisms, Carbon and Nitrogen Cycling, (Ed by O. Andren, T. Lindberg, K Paustian and T. Rosswall), pp. 84-125. Munksgaard, Copenhagen, Denmark.

Andre, H.M., Noti, M.I. and Lebrun, P. (1994). The soil fauna - the other last biotic frontier. Biodiversity and Conservation, 3(1), 45-56.

Arshad, M. A. and Schnitzer M. (1987). The chemistry of a termite Fungus Comb. Plant Soil 98, 247-256.

Baath, E., Berg, B., Lohm, U., Lundgren, B., Lundkvist, H., Rosswall, T., Söderström, B. and Wiren, A. (1980). Effects on experimental acidification and liming on soil organisms and decomposition in a Scots pine forest. Pedobiologia 20, 85-100.

Bachelier, G (1978). La Faune des sols, son Ecologie, son Action. ORSTOM, Paris, France

Bal, L. (1982). Zoological Ripening of Soils. PUDOC, Wageningen, The Netherlands.

Bamforth, S.S. (1988). Interactions between protozoa and other organisms. Agric. Ecosyst. Environ. 24, 229-234.

Barois, I. (1987). Interactions entre les Vers de Terre (Oligochata) tropicaux géophages et la microflore pour l'exploitation de la matière organique du sol. $\mathrm{PhD}$ thesis, University of Paris VI. $301 \mathrm{pp}$.

Barois, I. and Lavelle, P. (1986). Changes in respiration rate and some physicochemical properties of a tropical soil during transit through Pontoscolex corethrurus (Glossoscolecidæ, Oligochæta). Soil Biol. Biochem. 18 (5), 539-541.

Barois, I., Verdier, B., Kaiser, P., Mariotti, A., Rangel, P. and Lavelle, P. (1987) .Influence of the tropical earthworm Pontoscolex corethrurus (Glossoscolecidæ) on the fixation and mineralization of nitrogen. In: On Earthworms, (Ed. by A.M. Bonvicini and P. Omodeo), pp. 151-158. Mucchi, Bologna, Italy.

Berthelin, J., Souchier, B. and Toutain, F. (1979). Intervention des phénomènes biologiques dans l'altération. Sci. du Sol 2 (3), 175-187.

Bocock, K.L. (1963). The digestion and assimilation of food by Glomeris. In: Soil Organisms (Ed. by Doeksen, J. and Van der Drift J.) pp. 86-91. North Holland, Amsterdam, The Netherlands

Blanchart, E. (1992). Restoration by earthworms (Megascolecidae) of the macroaggregate structure of a destructured savanna soil under field conditions. Soil Biol. Biochem. 24 (12), 1587-1594.

Blanchart, E., Lavelle, P. and Spain, A. (1989). Effects of two species of tropical earthworms (Oligochaeta: Eudrilidae) on the size distribution of aggregates in an african soil. Rev. d'Ecol. Biol. du Sol 26, 417-425.

Blanchart, E., Bruand, A. and Lavelle, P. (1993). The physical structure of casts of Millsonia anomala (Oligochaeta: Megascolecidae) in shrub savanna soils (Côte d'Ivoire). Geoderma, 56 119-132.

Blanchart, E., Lavelle, P., Brandean, E., Le Bissonais, Y. and Valentin, C. (1996). Regulation of soil structure by geophagous earthworm activities in humid savannahs of Côte d' Ivoire. Soil. Biol. Biochem. (in press). 
Bloem, J., EllenBroek, F.M., Bär-Gilissen, M.J.B. and Cappenberg, T.E. (1989). Protozoan grazing and bacterial production in stratified lake Vechten estimated with fluorescently labeled bacteria and by thymidine incorporation. Appl. Environ. Microbiol. 55 (7), 1787-1795.

Bouché, M.B. and Kretzschmar, A. (1974). Fonction des lombriciens. II. recherches méthodologiques pour l'analyse du sol ingéré (étude du peuplement de la station RCP 165/PBI). Rev. d'Ecol. Biol. du Sol 11 (1), 127-139.

Bouché, M.B., Rafidison, Z. and Toutain, F. (1983). Etude de l'alimentation et du brassage pédo intestinal du lombricien Nicodrilus velox (Annelida, Lombricidae) par l'analyse élémentaire. Rev. d'Ecol. Biol. du Sol 20 (1), 49-75.

Boyer, P. (1982). Quelques aspects de l'action des termites sur les argiles. Clay Mineral. 17, 453-462.

Breznak, J.A. (1984). Biochemical aspects of symbiosis between termites and their intestinal microbiota, In: Invertebrate-microbial interactions (Ed by J.M. Anderson, A.D.M. Rayner and D.W.H. Walton), pp.173-24. Cambridge University Press, Cambridge, UK.

Brossard, M., Lavelle, P and Laurent, J.Y. (1996). Digestion of a vertisol by an endogeic earthworm (Polypheretima elongata, Megascolecidae) increases soil phosphate extractibility). Euro. J. Soil Biol. (in press).

Buse, A. (1990). Influence of earthworms on nitrogen fluxes and plant growth in cores taken from variously managed upland pastures. Soil Biol. Biochem. 22 (6), 775-780.

Butler, J.H.A. and Buckerfield, J.C. (1979). Digestion of lignin by termites. Soil Biol. Biochem. 11, 507-513.

Casenave, A. and Valentin, C. (1989). Les états de Surface de la Zone Sahélienne. Influence sur l'Infiltration. ORSTOM, Paris, France.

Casida, L.E. Jr. (1988). Minireview: Nonobligate bacterial predation of bacteria in soil. Microb. Ecol. 15 1-8.

Chakraborty, S., Theodorou, C. and Bowen, G. (1983). Amoebae from a take-all suppressive soil which feed on Gaeumannomyces graminis tritici and other soil fungi. Soil Biol. Biochem. 15, 17-24.

Chaussod, R., Nicolardot, B., Catroux, G. and Chretien, J. (1986). Relations entre les caractéristiques physico-chimiques et microbiologiques de quelques sols cultivés. Sci. du Sol 2, 213-226.

Clarholm, M. (1984). Microbes as predator or prey. Heterotrophic, free-living protozoa: neglected microorganisms with an important task in regulating bacteria populations. In: Current Perspectives on Microbial Ecology (Ed. by M.J. Klug and C.A. Reddy), pp.321-326. Washington DC, USA.

Clarholm, M. (1985). Possible roles for roots, bacteria, protozoa and fungi in supplying nitrogen to plants. In: Ecological Interactions in Soil; Plants, Microbes and Animals (Ed. by D. Atkinson, A.H. Fitter, D.J. Read and M.B. Usher), pp. 355-365. Blackwell Scientific Publications, Oxford, UK.

Clarholm, M. and Rosswall, T. (1980). Biomass and tumover of bacteria in a forest soil and a peat. Soil Biol. Biochem. 12, 49-57.

Clements, R.O., Murray, P.J. and Sturdy, R.G. (1991). The impact of 20 years' absence of earthworms and three levels of $\mathrm{N}$ fertilizers on a grassland soil environment. Agric. Ecosyst. Environ. 36, 75-85.

Coleman, D.C. (1985). Through a ped darkly: an ecological assessment of root-soilmicrobial-faunal interactions. In: Ecological Interactions in Soil; Plants, Microbes and Animals (Ed. by D. Atkinson, A.H. Fitter, D.J. Read and M.B. Usher), pp. 1-21 Blackwell Scientific Publications, Oxford, UK. 
Coleman, D.C., Anderson, R.V., Cole, C.V., McClellan, J.F., Woods, L.E., Trofymow, J.A. and Elliott, E.T. (1984a). Roles of protozoa and nematodes in nutrient cycling. In: Microbial-plant Interaction pp.17-28. ASA Special Publication No 47 Madison, E. Winsconsin.

Coleman, D.C., Ingham, R.E., McClellan, J.F. and Trofymow, J.A. (1984b). Soil nutrient transformations in the rhizosphere via animal-microbial interactions. In: Invertebrates-microbial interactions. (Ed. by J.M. Anderson, D.M. Rayner and D.W.H. Walton), pp. 35-58. Cambridge University Press, Cambridge, UK.

Coleman, D.C., Brussard, L., Beare, M.H., Hendrix, P.F., Hassink, J., Heijnen, C.E. and Marinissen, J.C.Y. (1989). Microbial-Faunal Interactions as they Influence Soil Organic Matter dynamics. pp.175-179. Kyoto, Japan.

Collins, N.M. (1983). Termite populations and their role in litter removal in Malaysian rainforests. In: Tropical Rainforests: Ecology and Management (Ed. by S.L. Sutton, T.C. Whitmore and L.O. Chadwick). Blackwell, Oxford, UK.

Cooke, R.C. and Godfrey, B.E.S. (1964). A key to the nematode-destroying fungi. Trans. Bri. mycol. Soc. 47, 61-74.

Cortez, J., Hameed, R. and Bouché, M.B. (1989). C. and N. transfer in soil with or without earthworms fed with ${ }^{14} \mathrm{C}$. and ${ }^{15} \mathrm{~N}$-labelled wheat straw. Soil Biol. Biochem. 21 (4), 491-497.

Coûteaux, M.M. (1985a). Relationships between testate amoebae and fungi in humus microcosms. Soil Biol. Biochem. 17 (3), 339-345.

Coûteaux, M.M. (1985b). Relation entre la densité apparente d'un humus et l'aptitude à la croissance de ses Ciliés. Pedobiologia 28, 289-303.

Cowie, R.H., Logan, J.W.M. and Wood, T.G.(1991). Termite damage and control in tropical forestry. In Advances in Management and Conservation of Soil Fauna (Ed. by G.K. Veeresh et al.), pp.161-167. Oxford \& IBH, New Dehli, India.

Cox, G.W., Gakahu, C.G. and Waithaka, J.M. (1989). The form and small stone content of large earth mounds constructed by mole rats and termites in Kenya. Pedobiologia 33, 307-314.

Curl, E.A. (1988). The role of soil microfauna in plant-disease suppression. CRC Crit. Rev. Plant Sci. 7 (3), 175-196.

Curry, J.P. and Boyle, K.E. (1987). Growth rates, establishment and effect on herbage yield of introduced earthworms in grassland on reclaimed cutover peat. Biol. Fertil. Soils 3, 95-98.

Darbyshire, J.F. and Greaves, M.P. (1973). Bacteria and Protozoa in the rhizosphere. Pesticide Sci. 4, 349-360.

Darlington, J.P.E.C. (1982). The underground passages and storage pits used in foraging by a nest of the termite Macrotermes michaelseni in Kajiado, Kenya. Kenya J. Zool. 198, 237-247.

Darwin, C. (1881). The Formation of Vegetable Mould Through the Action of Worms with Observations on Their Habits. Murray, London, UK.

Dash, M.C., Senapati, B.K. and Mishra, C.C. (1980). Nematode feeding by tropical earthworms. Oikos 34, 322-329.

Deleporte, S. (1987). Rôle du Diptère Sciaridae Bradysia confinis (Winn., Frey) dans la dégradation d'une litière de feuillus. Rev. d'Ecol. Biol. du Sol 24, 341-358.

Deleporte, S. and Rouland, C. (1991). Etude préliminaire de l'équipement digestif osidasique de Bradysia confinis (Diptera, Sciaridae): implications dans la dégradation de la matière organique. Compte-Rend. l'Acad. Sci. Paris, 312 (III), 165-170.

Derouard, L., Tondoh, J., Vilcosqui and Lavelle, P. (1996). Species-specific effects in the response of tropical annual crops to the inoculation of earthworms. Short-scale experiments at Lamto (Côte d'Ivoire). Soil Biol. Biochem., (in press). 
Didden, W.A.M. (1990). Involvement of Enchytraeidae (Oligochaeta) in soil structure evolution in agricultural fields. Biol. Fertil. Soils 9, 152-158.

Dokuchaev, V.V. (1889). The zones of Russia (in Russian). Akad. Nauk Moscow, 6.

Elkins, N.Z., Sabol, G.Z., Ward, T.J., \& G, W.W. (1986). The influence of subterranean termites on the hydrological characteristics of a Chihuahuan desert ecosystem. Oecologia 68, 521-528.

Elliott, E.T., Anderson, R.V., Coleman, D.C. and Cole, C.V. (1980). Habitable pore space and microbial trophic interactions. Oikos 35, 327-335.

Elliott, E.T., Hunt, H.W. and Walter, D.E. (1988). Detrital foodwebs interactions in north american grassland ecosystems. Agric. Ecosyst. Environ. 24, 41-56.

Eschenbrenner, V. (1986). Contribution des termites à la macro-agrégation des sols tropicaux. Cahiers ORSTOM, Sér. Pédolog. 22 (4), 397-408.

Ferrière, G. and Bouché, M. (1985). Première mesure écophysiologique d'un débit d'éléments dans un animal endogé: le débit d'azote de Nicodrilus longus longus Ude (Lumbricidae, Ologochaeta) dans la prairie de Citeaux. Comptes Rend. l'Acad. Sci. Paris 301, 789-794.

Freckman, D.W. (1988). Bacterivorous nematodes and organic-matter decomposition. Agric. Ecosyst. Environ. 24, 195-217.

Galli, E., Tomati, U. and Di Lena, G. (1990). Effect of earthworm casts on protein synthesis in Agaricus bisporus. Biol. Fertil. Soils 9, 290-291.

Garnier-Sillam, E., Villemin, G., Toutain, F. and Renoux, J. (1987). Contribution à l'étude du rôle des termites dans l'humification des sols forestiers tropicaux. In: Micromorphologie des Sols - Soil Micromorphology (Ed. by N. Fedoroff, L.M. Bresson and M.A. Courty), pp. 331-335. AFES, Paris, France.

Garnier-Sillam, E., Braudeau, E. and Tessier, D. (1991). Rôle des termites sur le spectre poral des sols forestiers tropicaux. Cas de Thoracotermes macrothorax Sjöstedt (Termitinae) et de Macrotermes mülleri (Sjöstedt) (Macrotermitinae). Insect. Soc. 38, 397-412.

Gilot, C. (1994). Effets de l'introduction du ver géophage tropical Millsonia anomala Omodeo en systèmes cultivés sur les caractéristiques des sols et la production végétale en moyenne Côte d'Ivoire. PhD thesis, Paris VI/INAPG, France.

Gourbière, F. (1982). Pourriture blanche de la litière d'Abies alba Mill. I. - Evolution de la litière sous l'action des basidiomycètes du genre Collybia. Rev. d'Ecol. Biol. du Sol 19 (2), 163-175.

Grassé, P.P. (1984). Termitologia. Masson, Paris, France.

Griffiths, B.S., Wood, S. and Cheshire, M.V. (1989). Mineralisation of ${ }^{14} \mathrm{C}$-labelled plant material by Porcellio scaber (Crustacea, Isopoda). Pedobiologia 33, 355-360.

Haimi, J., Huhta, V. and Boucelham, M. (1992). Growth increase of birch seedlings under the influence of earthworms. A laboratory study. Soil Biol. Biochem. 24 (12), 1525-1528.

Hanlon, R.D.G. (1981). Some factors influencing microbial growth on soil animal faeces. II. Bacterial and fungal growth on soil animal faeces. Pedobiologia 21, $264-270$.

Hanlon, R.D.G. and Anderson, J.M. (1980). Influence of Macroarthropod feeding activities on microflora in decomposing oak leaves. Soil Biol. Biochem. 12, 255-261.

Harris, W.V. (1969). Termites as Pests of Crops and Trees. Commonwealth Institute of Entomology, London, UK.

Hassal, M. and Rushton, S.P. (1982). The role of coprophagy in the feeding strategies of terrestrial isopods. Oecologia 53, 374-381.

Hassall, L., Turner, J.G. and Rands, M.R.W. (1987). Effects of terrestrial isopods on the decomposition of woodland leaf litter. Oecologia 72, 597-604. 
Hattori, T. (1988). Soil aggregates as microhabitats of microorganisms. Rep. Inst. Agric. Res., Tohaten University, 37, 23-36.

Hendrix, P.F., Parmelee, R.W., Crossley, D.A. Jr., Coleman, D.C., Odum, E.P. and Groffman, P.M. (1986). Detritus food webs in conventional and non-tillage agroecosystems. BioScience 36 (6), 374-380.

Hoeksema, K.J. and Jongerius, A. (1959). On the influence of earthworms on the soil structure in mulched orchards. Proc. Int. Symp. Soil Struct. pp.188-194, Ghent.

Holt, J.A. and Coventry, R.J. (1982) Occurence of termites (isoptera) on cracking clay soils in northeastern Queensland. J. Aust. Entomol. Soc. 21, 135-136.

Hoogerkamp, M., Rogaar, H. and Eijsackers, H.J.P. (1983). Effect of earthworms on grassland on recently reclaimed polder soils in the Netherlands. In: Earthworm Ecology: from Darwin to vermiculture (Ed. by J.E. Satchell), pp.85-105. Chapman and Hall, London, New York.

Hopp, H. (1973). What every Gardener Should Know About Earthworms. Garden Way Publishing Co., Vermont, USA.

Hunt, H.W., Coleman, D.C., Ingham, E.R., Ingham, R.E., Elliott, E.T., Moore, J.C., Rose, S.L., Reid, C.P.P. and Morley, C.R. (1987). The detrital food web in a shortgrass prairie. Biol. Fertil. Soils 3, 57-68.

Ingham, R.E., Trofymow, J.A., Ingham, E.R. and Coleman, D.C. (1985). interactions of bacteria, fungi, and their nematode grazers: Effects on nutrient cycling and plant growth. Ecolog. Monographs 55, 119-140.

Ingham, E.R., Trofymow, J.A., Ames, R.N., Hunt, H.W., Morley, C.R., Moore, J.C. and Coleman, D.C. (1986). Trophic interactions and nitrogen cycling in a semiarid grassland soil II. System responses to removal of different groups of soil microbes or fauna. J. Appl. Ecol. 23, 615-630.

Ingham, E.R., Coleman, D.C. and Moore, J.C. (1989). An analysis of food web structure and function in a shortgrass prairie, a mountain meadow and a lodgepole pine forest. Can. J. Soil Sci. 66, 261-272.

Jeanson, C. (1979). Structuration du sol par la faune terricole, incidences sur les concentrations organo-minérales. In: Migrations Organo-minérales dans les Sols Tempérés, pp.113-123. CNRS, Nancy, France.

Jenkinson, D.S. (1966). The Priming Action. J. Appl. Rad. Isotopes Suppl. pp.199-208.

Jenkinson, D.S. and Ladd, J.N. (1981). Microbial biomass in soil: measurement and turnover. In: Soil Biochemistry (Ed. by J.N. Ladd and E.A. Paul), pp.415-471. Dekker, New York, USA.

Jenkinson, D.S. and Rayner, J.H. (1977). The turnover of soil organic matter in some of the Kothamsted classical experiments. Soil Sci. 123, 298-305.

Kladivko, E.J., Mackay, A.D. and Bradford, J.M. (1986). Earthworms as a factor in the reduction of soil crusting. Soil Sci. Soc. Am. J. 50 (1), 191-196.

Kretzschmar, A. (1982). Description des galeries de vers de terre et variations saisonnières des réseaux (observations en conditions naturelles). Rev. d'Ecol. Biol. du Sol 19, 579-591:

Kretzschmar, A. (1987). Caractérisation microscopique de l'activité des lómbriciens endogés. In: Micromorphologie des Sols - Soil Micromorphology (Ed. by N. Fedoroff, L.M. Bresson and M.A. Courty), pp.325-331. AFES, Paris, France.

Kretzschmar, A. (1989). Galeries de lombriciens en réseaux: structures fonctionnelles et signatures comportementales. PhD thesis, Paris XI, France.

Kuikman, P.J. and van Veen, J.A. (1989). The impact of protozoa on the availability of bacterial nitrogen to plants. Biol. Fertil. Soils 8, 13-18.

Kumarasinghe, N.C. (1991). Studies on the damage by termites to seed setts and to postharvest stubbles of sugarcane plantations in the dry zone of Sri Lanka. In: Advances in Management and Conservation of Soil Fauna, (Ed. by G.K. Veeresh, D. Ranagopal and C.A. Viraktamath), pp.147-154. Oxford \& IBH, New Dehli, India. 
Lal, R. (1988). Effects of macrofauna on soil properties in tropical ecosystems. Agric. Ecosyst. Environ. 24, 101-116.

Lamparski, F., Kobel-Lamparski, A. and Kaffenberger, R. (1987). The burrows of Lumbricus badensis and Lumbricus polyphemus. In: On earthworms (Ed. by A.M. Bonvicini Pagliai and P. Omodeo), pp.131-140. Mucchi editore, Modena, Italy.

Lavelle, P. (1978). Les Vers de Terre de la savane de Lamto (Côte d'Ivoire): peuplements, populations et fonctions dans l'écosystème. Thèse d'Etat, Paris VI Publication du Laboratoire de Zoologie de l'ENS n ${ }^{\circ} 12$.

Lavelle, P. (1984). The soil system in the humid tropics. Biol. Int. 9, 2-15.

Lavelle, P. (1988). Earthworm activities and the soil system. Biol. Fertil. Soil, 6, 237-251.

Lavelle, P. and Gilot, C. (1994). Priming effects of macroorganisms on microflora: A key process of soil function? In: Beyond the Biomass, (Ed. by K. Ritz, J. Dighton and K. Giller), pp. 176-181. Wiley-Sayce, Chichester, UK.

Lavelle, P., Barois, I., Cruz, C., Hernandez, A., Pineda, A. and Rangel, P. (1987). Adaptative strategies of Pontoscolex corethrurus (Glossoscolecidæ, Oligochæta), a peregrine geophagous earthworm of the humid tropics. Biol. Fertil. Soils, 5, $188-194$.

Lavelle, P., Alegre, J., Barois, I., Fragoso, C., Gilot, C., Gonzalez, C., Kanyonyo, ka Kajondo, Martin, A., Melendez, G., Moreno, A., Pashanasi, B., Patron, C. and Schaefer, R. (1992a). Conservation of Soil Fertility in low Input Agricultural Systems of the Humid Tropics by Manipulating Earthworm Communities. CCE-STD2 programme. Final report. ORSTOM, Bandy, France.

Lavelle, P., Melendez, G., Pashanasi, B., Szott, L. and Schaefer, R. (1992b) Nitrogen mineralization and reorganization in casts of the geophagous tropical earthworm Pontoscolex corethurus (Glossoscolecidae). Biol. Fertil. Soil 14, 49-53.

Lavelle, P., Spain, A.V., Blanchart, E., Martin, A. and Martin, S. (1992c). The impact of soil fauna on the properties of soils in the humid tropics. In: Myths and Science of Soils of the Tropics (Ed. by P.A. Sanchez and R. Lal), pp. 157-185. SSSA Special Publication, Madison, Wisconsin, USA.

Lavelle, P., Blanchart, E., Martin, A., Martin, S., Barois, I., Toutain, F., Spain, A.and Schaefer, R. (1993). A hierarchical model for decomposition in terrestrial ecosystems. Application to soils in the humid tropics. Biotropica 25 (2), 130-150.

Lavelle, P., Lattaud, C., Trigo, D. and Barois, I. (1994b). Mutualism and Biodiversity in soils. Pl. Soil $170(1), 23-33$.

Lee, K.E. (1985). Earthworms: Their Ecology and Relationships with Soils and Land use. Academic Press, New York, USA.

Lee, K.E. and Wood, T.G. (1971). Termites and Soils, Academic Press, London, UK.

Lepage, M.G. (1974) Les termites d'une savane sahélienne (Ferlo septentrional, sénégal): peuplement, populations, consommation, rôle dans l'écosystème. $\mathrm{PhD}$ thesis, Dijon, France.

Lepage, M.G. (1979). La récolte en strate herbacée de Macrotermes aff. subhyalinus (Isoptera: Macrotermitinae) dans un écosystème semi-aride (Kajiado-Kenya). C.R. UIEIS section Française, Lausanne, 7-8 September 1979.

Lepage M.G. (1981). L'impact des populations récoltantes de Macrotermes michaelseni (Sjöstedt) (Isoptera, Macrotermitinae) dans un écosystème semi-aride (Kajiado-Kenya). I.-L'activité de récolte et son determinisme. Insect. Soc. 28 (3), 297-308.

Lewis, D.H. (1985). Symbiosis and mutualism: crisp concepts and soggy semantics. In: Biology of Mutualism (Ed. by D.H. Boucher), pp. 29-42. Croom Helm, Beckenham, UK. 
Lopes-Assad, M.L (1987). Contribution a l'étude de la macroporosité lombricienne de différents types de sols de France. Université, USTL, Montpellier, France.

Lòpez-Hernàndez, D. and Febres, A. (1984). Changements chimiques et granulométriques produits dans des sols de Côte d'Ivoire par la présence de trois espèces de termites. Rev. Ecol. Biol. du Sol 21 (4), 477-489.

Lòpez-Hernandez, D., Fardeau, J.C. and Lavelle, P. (1993). Phosphorus transformations in two P-sorption contrasting tropical soils during transit through Pontoscolex corethrurus (Glossoscolecidae, Oligochaeta). Soil Biol. Biochem. 25 (6), 789-792.

MacKay, W.P. and Whitford, W.G. (1988). Spatial variability of termite gallery production in Chihuahuan desert plant communities. Sociobiology 14 (1), 281-289.

MacKay, W.P., Blizzard, J.H., Miller, J.J. and Whitford, W.G. (1985). Analysis of above-ground gallery construction by the subterranean termite Gnathamitermes tubiformans (Isoptera: Termitidae). Environ. Entomol. 14 (4), 470-474.

Marinissen, J.C.Y. and Van den Bosch, F. (1992). Colonization of new habitants by earthworms. Oecologia 91, 371-376.

Martikainen, E. and Huhta, V. (1990). Interactions between nematodes and predatory mites in raw humus soil: a microcosm experiment. Rev. d'Écol. Biol. du Sol 27 (1), 13-20.

Martin, A. (1991). Short-term and long-term effect of the endoge ice earthworm Millsonia anomala (Omodeo) (Megascolecidae, Oligochaeta) of a tropical savanna, on soil organic matter. Biol. Fertil. Soil. 11, 234-238.

Martin, A. and Lavelle, P. (1992). Effect of soil organic matter quality on its assimilation by Millsonia anomala, a tropical geophagous earthworm. Soil Biol. Biochem. 24 (12), 1535-1538.

Martin, A. and Marinissen, J.C.Y. (1993). Biological and physico-chemical processes in excrements of soil animals. Geoderma 56, 331-347.

Martin, A., Cortez, J., Barois, I. and Lavelle, P. (1987). Les mucus intestinaux de Ver de Terre, moteur de leurs interactions avec la microflore. Rev. d'Ecol. Biol. du Sol 24 (4), 549-558.

Martin, A., Mariotti, A., Balesdent, J., Lavelle, P. and Vuattoux, R. (1990). Estimates of the organic matter turnover rate in a savanna soil by the ${ }^{13} \mathrm{C}$ natural abundance. Soil Biol. Biochem. 22 (4) 517-523.

Martin, A., Mariotti, A., Balesdent, J. and Lavelle, P. (1991). Soil organic matter assimilation of a geophagous tropical earthworm based on ${ }^{13} \mathrm{C}$ measurements. Ecology 73 118-128.

Meyer, J.A. (1960). Résultats agronomiques d'un essai de nivellement des termitières réalisé dans la cuvette centrale Congolaise. Bull. d'Agric. Congo Belge. 51, 1047-1059.

Minderman, G. (1968). Addition, decomposition and accumulation of organic matter in forests. J. Ecol. 56 355-362.

Mitsui, Y. (1985). Distribution and ecology of nematode-trapping fungi in Japan. $J A R Q 18$ (3), 182-193.

Moore, J.C. (1988). The influence of microarthropods on symbiotic and non-symbiotic mutualism in detrital-based below-ground food webs. Agric. Ecosys. Environ. 24, 147-159.

Moore, J.C. and de Ruiter, P.C. (1991). Temporal and spatial heterogeneity of trophic interactions within below-ground foodwebs. Agri. Ecosyst. Environ. 34, 371-397.

Moore, J.C., DeRuiter, P.C. and Hunt H.W. (1993). Soil invertebrate/micro-invertebrate interactions: disproportionate effects of species on food web structure and function. Vet. Pathol. 48, 247-260.

Moorhead, D.L. and Reynolds, J.F. (1989). The contribution of abiotic processes to buried litter decomposition in the northern Chihuahuan Desert. Oecologia 79, 133-135. 
Muller, P.E. (1887). Studien ïber die naturlichen Humusformen und deren Einwirkung auf vegetation und Boden. Springer, Berlin, Germany.

Nye, P.H. (1955). Some soil-forming processes in the humid tropics. IV - The action of the soil fauna. J. Soil. Sci. 6(1), 73-83.

Okello-Oloya, T. and Spain, A.V. (1986). Comparative growth of two pasture plants from northeastern Australia on the mound materials of grass and litter-feeding termites (Isoptera: Termitidae) and on their associated surface soils. Rev. d'Écol. Biol. du Sol 23 (4), 381-392.

Okwakol, M.J.N. (1987). Effects of Cubitermes testaceus (Williams) on some phy sical and chemical properties of soil in a grassland area of Uganda. Afr. J. Ecol. 25, 147-153.

Pashanasi, B., Melendez, G., Szott, L. and Lavelle, P. (1992). Effect of inoculation with the endogeic earthworm Pontoscolex corethrurus (Glossoscolecidae) on $\mathrm{N}$ availability, soil microbial biomass and the growth of three tropical fruit tree seedlings in a pot experiment. Soil Biol. Biochem. 24 (12), 1655-1660.

Pashanasi, B., Lavelle, P. and Alegre, J. (1996). Effect of inoculation with the endogeic earthworm Pontocolex corethrurus on soil chemical characteristics and plant growth in a low-input agricultural system of Peruvian Amazonia. Soil Biol. Biochem. 28 (6), 801-810.

Pedro, G. (1989). Geochemistry, mineralogy and microfabric of soils. In: Soils and their Management: a Sino-European Perspective (Ed. by W.T. Maltby), pp. 59-90. Elsevier Applied Science, Bruxelles, Belgium.

Petersen, H. and Luxton, M. (1982). A comparative analysis of soil fauna populations and their role in decomposition processes. Oikos 39 (3), 287-388.

Petz, W., Foissner, W., Wirnsberger, E., Krautgartner, W.D. and Adam, H. (1986). Mycophagy, a new feeding strategy in Autochthonous soil ciliates. Naturwissenschaften 73, 560-561.

Piearce, T.G. and Phillips, M.J. (1980). The fate of ciliates in the earthworm gut: an in vitro study. Micro. Ecol. 5, 313-319.

Pop, V.V. and Postolache, T. (1987). Giant earthworms build up vermic mountain rendzinas, In: On Earthworms (Ed. by A. Bonvicini Pagliai and P. Omodeo), pp. 141-150, Mucchi, Italy.

Rajagopal, D., Sathyanarayana, T. and Veeresh, G.K. (1982). Physical and chemical properties of termite mound and surrounding soils of Karnataka. J. Soil Biol. Ecol. 2, 1831.

Rajagopal, D., Veeresh, G.K. and Kumar, N.G. (1991). Assessment of losses of nutrients in dung and farmyard manure due to termite foraging In: Advances in Management and conservation of soil fauna (Ed. by G.K. Veeresh, D.R. Jagopal, C.A. Viraktamath. et. al.), pp. 155-160. Oxford and IBH, New Dehli, India.

Reyes, V.G. and Tiedje, J.M. (1976). Metabolism of 14C-labelled plant materials by woodlice (Tracheoniscus rathkei (brandt) and soil micro-organisms. Soil Biol. Biochem. 8, 103-108.

Rose, C.J. and Wood, A.W. (1980). Some environmental factors affecting earthworms populations and sweet potato production in the Tari Basin, Papua New Guinea Highlands. Papua N. G. Agric. J. 31, 1-10.

Rouelle, J. (1983). Introduction of amoebae and Rhizobium japonicum into the gut of Eisenia foetida (Sav.) and Lumbricus terrestris L. In: Earthworm Ecology: from Darwin to Vermicuture (Ed. by J.E. Satchell), pp. 375-381. Chapman and Hall, London. 
Rouland, C., Civas, A., Renoux, J. and Petek, F. (1988). Synergistic activities of the enzymes involved in cellulose degradation, purified from Macrotermes mülleri and from its symbiotic, fungus Termitomyces sp. Comp. Biochem. Physiol. B 91 (3), 459-465.

Rouland, C., Brauman, A., Keleke, S., Labat, M., Mora, P. and Renoux, J. (1990). Endosymbiosis and exosymbiosis in the fungus-growing termites. In: Microbiology in Poecilotherms (Ed. by R. Lésel), pp. 79-82. Elsevier Science Publishers, B.V. (Biomedical Division), Amsterdam, The Netherlands

Rouland, C., Lenoir, F. and Lepage, M. (1991). The role of symbiotic fungus in the digestive metabolism of several species of fungus-growing termites. Comp. Biochem. Physiol. A 99 (4), 657-663.

Schaefer, M. and Schauermann, J. (1990). The soil fauna of beech forests: comparison between a mull and a moder soil. Pedobiologia 34(5), 299-314.

Scharpenseel, H.W., Becker, Heidmann, P., Neue, H.U. and Tsutsuki, K. (1989). Bomb-carbon, ${ }^{14} \mathrm{C}$-dating and ${ }^{13} \mathrm{C}$-measurements as tracers of organic matter dynamics as well as of morphogenetic and turbation process. In The Science of Total Environment, pp. 99-110. Elsevier Science, Amsterdam, The Netherlands.

Seastedt, T.R., Todd, T.C. and James, S.W. (1987). Experimental manipulations of arthropod, nematode and earthworm communities in a north American tallgrass prairie. Pedobiologia 30, 9-17.

Senapati, B.K., Pani, S.C. and Kabi, A. (1985). Effects of earthworm and green manuring on paddy. Proc. Soil Biol. Symp, Hisar, February 1985, pp. 71-75.

Setälä, H. and Huhta, V. (1991). Soil fauna increase Betula pendula growth: laboratory experiments with coniferous forest floor. Ecology 72 (2), 665-671.

Setälä, H., Martikainen, E., Tynismaa, M. and Huhta, V. (1990). Effects of soil fauna on leaching of nitrogen and phosphorus from experimental systems simulating coniferous forest floor. Biol. Fertil. Soils 10, 170-177.

Setälä, H., Tyynismaa, M., Martikainen, E. and V, H. (1991). Mineralization of C, N and $\mathrm{P}$ in relation to decomposer community structure in coniferous forest soil. Pedobiologia 35 (5), 285-296.

Sharpley, A.N. and Syers, J.K. (1976). Potential role of earthworm casts for the phosphorus enrichment of run-off waters. Soil Biol. Biochem. 8, 341-346.

Shaw, C. and Pawluk, S. (1986). The development of soil structure by Octolasion tyrtaeum, Aporrectodea turgida and Lumbricus terrestris in parent materials belonging to different textural classes. Pedobiologia 29 327-339.

Sohlenius, B., Boström, S. and Sandor, A. (1988). Carbon and nitrogen budgets of nematodes in arable soil. Biol. Fertil. Soils 6, 1-8.

Spain, A.V., John, R.D. and Okello-Oloya, T. (1983). Some pedological effects of selected termite species at three locations in north-eastern Australia. In: New Trends in Soil Biology, (Ed. by P.H. Lebrun et al.,), pp. 143-149. Dieu-Brichart, Ottignies-Louvain-la-Neuve, Louvain-la-Neuve, France.

Spain, A.V., Lavelle, P. and Mariotti, A. (1992). Stimulation of plant growth by tropical earthworms. Soil Biol. Biochem. 24 (12), 1629-1634.

Stockdill, S.M.J. (1959). Earthworms improve pasture growth. N. Z. J. Agric. 98, 227-233.

Stockdill, S.M.J. (1982). Effects of introduced earthworms on the productivity of New Zealand pastures. Pedobiologia 24, 29-35.

Stork, N.E. and Eggleton, P. (1992). Invertebrates as determinants and indicators of soil quality. Am. J. Altern. Agric. 7 (1) (2) 38-47.

Stout, J.D. and Heal, O.W. (1967). Protozoa. In: Soil Biology (Ed. by A Burges and F Raw), pp. 149-195. Academic Press, London, New York.

Swift, M.J. (1986). Tropical soil biology and fertility (TSBF): inter-regional research planning workshop. Report of the third Workshop of the decade of the Tropics/TSBF program. Biology Int. (Special Issue 13). 
Swift, M.J., Heal, O.W. and Anderson, M.J. (1979). Decomposition in Terrestrial Ecosystems. Blackwell Scientific, Oxford, UK.

Swift, M.J., Frost, P.G.H., Campbell, B.M., Hatton, J.C. and Wilson, K.B. (1989). N cycling in farming systems derived from savanna: perspectives and challenges, In: Ecology of Arable Lands (Ed. by M. Clarholm and L. Bergström), pp. 63-76. Kluwer Academic Publishers, The Netherlands.

Syers, J.K., Sharpley, A.N. and Keeney, D.R. (1979). Cycling of nitrogen by surfacecasting earthworms in a pasture ecosystem. Soil Biol. Biochem. 11, 181-185.

Tomati, U., Grappeli, A. and Galli, E. (1988). The hormone-like effect of earth worm casts on plant growth. Biol. Fertil. Soil 5, 288-294.

Toutain, F. (1987). Activité biologique des sols, modalités et lithodépendance. Biol. Fertil. Soil 3, 31-38.

Toutain. F., Villemin, G., Albrecht, A. and Reisinger, O. (1982). Etude ultra structurale des processus de biodégradation II. Modèle Enchytraeides-litière de feuillus. Pedobiologia 23, 145-156.

Trigo, D. and Lavelle, P. (1992). Changes in respiration rate and some physico-chemical properties of soil during gut transit through Allolobophora molleri (Lumbricidae). Biol. Fertil. Soil 15, 185-188.

Trofymow, J.A. and Coleman, D.C. (1982). The role of bacterivorous and fungivorous nematodes in cellulose and chitin decomposition., In: Nematodes in Soil Ecosystems (Ed. by D.W. Freckman), pp. 117-138. University of Texas Press, Austin, USA.

Urbanek, J. and Dolezal, F. (1992). Review of some case studies on the abundance and on the hydraulic efficiency of earthworm channels in Czechoslovak soils, with reference to the subsurface pipe drainage. Soil Biol. Biochem. 24 (12), 1563-1571.

Van Noordwijk, M. and de Willigen, P. (1986). Quantitative root ecology as element of soil fertility theory. Neth. J. Agric. Sci. 34, 273-281.

Vannier, G. (1985). Modes d'exploitation et partage des ressources alimentaires dans le système saprophage par les microarthropodes du sol. Bull. d'Ecolog. 16 (1), 19-34.

Verhoeff, H.A. and De Goede, R.G.M. (1985). Effects of Collembolan grazing on nitrogen dynamics in a coniferous forest. In: Ecological Interactions in Soil; Plants, Microbes and Animals (Ed. by D. Atkinson, A.H. Fitter, D.J. Read and M.B. Usher), pp. 367-376. Blackwell Scientific Publications, Oxford, UK.

Vinson, S.B. (ed) (1986). Economic Impact and Control of Social Insects. Praeger, New York, USA.

Whitford, W.G. (1989). Abiotic controls on the functional structure of soil food webs. Biol. Fertil. Soil 8, 1-6.

Wielemaker, W.G. (1984). Soil formation by termites, a study in the Kisii area, Kenya. Doctorate thèsis, Wageningen University, The Netherlands.

Williams, M.A.J. (1968). Termites and soil development near Brooks Creek, Northern Territory. Aust. J. Soil Sci. 31, 153-154.

Wood, T.G. (1978). Food and feeding habits of termites. In: Production Ecology of Ants and Termites, (Ed. by M.V. Brian), pp. 55-80. Cambridge University Press, Cambridge, UK.

Wood, T.G. (1988). Termites and soil environment. Biol. Fertil. Soils 6, 228-236.

Wolters, V. (1991). Soil invertebrates - Effets on nutrient turnover and soil structure - a review. Z. Pflanzenernähr Bodenk 154, 389-402.

Yeates, G.W. (1981). Soil nematode populations depressed in the presence of earthworms. Pedobiologia 22, 191-204.

Zhang, B.G., Rouland, C., Lattaud, C. and Lavelle, P. (1993). Origin and activity of enzymes found in the gut content of the tropical earthworm Pontoscolex corethrurus Müller. Eur. J. Soil Biol. 29 (1), 7-11. 